\title{
The Forms and Meaning of Ancient Judahite Sacrificial System: A Discussion Based on Leviticus 1-7
}

Yaw Adu-Gyamfi 1

${ }^{1}$ University of the Western Cape, South Africa and Ghana Baptist University College, Ghana.

\section{ABSTRACT}

Sacrifices are performed in almost every human society of which ancient Israel is not exempted. Since sacrifices do not take place anywhere and anyhow, the article describes sacred places and objects in ancient Israelite society.This article looks at the forms of the sacrifices and their meaning as described in Leviticus 1-7. It helps one to understand the purposes of performing these sacrifices. This article also shows the roles of both the priest and the offerors in performing sacrifices. The article, in addition, seeks to explain the role of blood in the ancient Israelite sacrificial system. The article demonstrates that sacrifice

Correspondence: Yaw Adu-Gyamfi Email: yawag156@gmail.com

Publication History

Received 5th October 2020, Accepted 30th October 2020 Published online 6th November 2020 was a means of restoring a broken relationship between YHWH and his people caused by their sins.

Keywords: forms and meaning, ancient Israel, sacrificial system, Leviticus 1-7

\section{INTIBODDCIION}

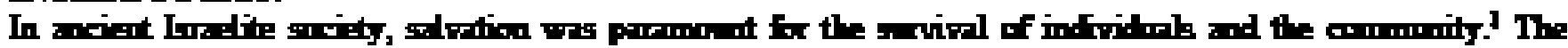

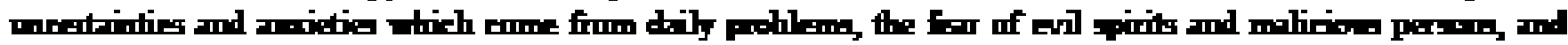

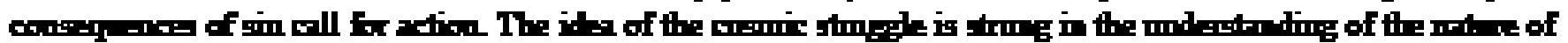

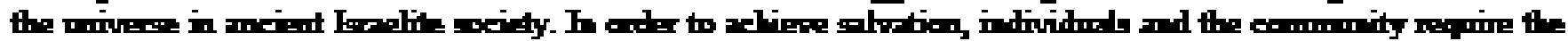

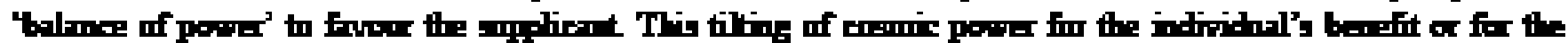

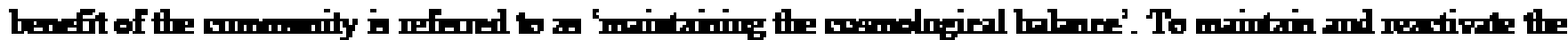

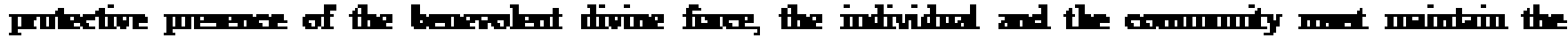

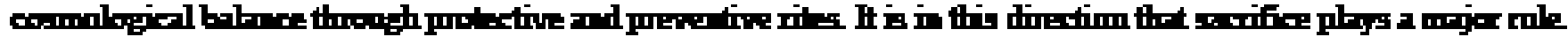

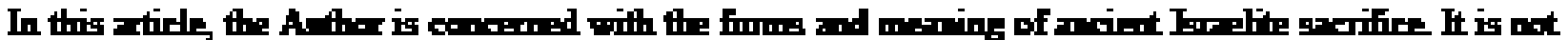

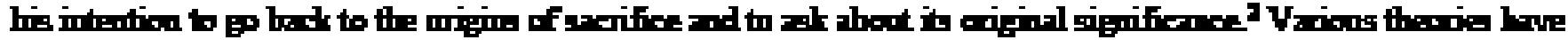

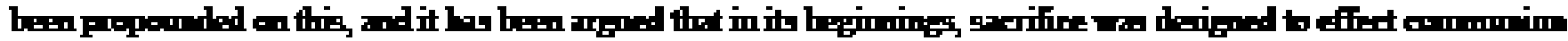

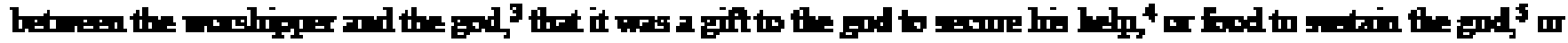

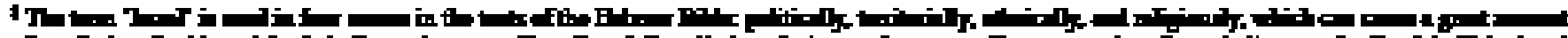
di

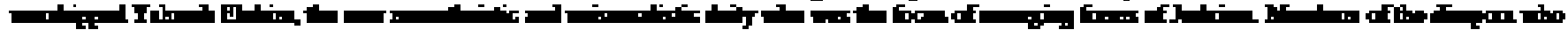

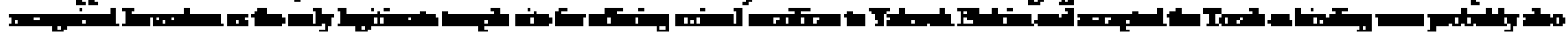

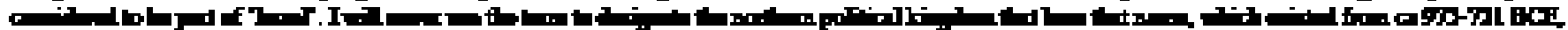

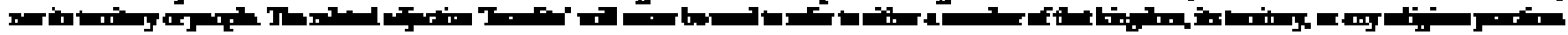

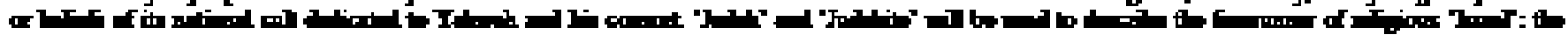

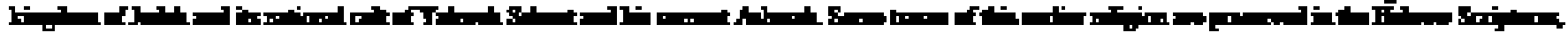

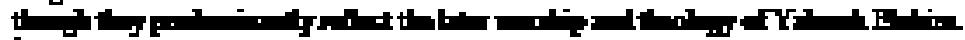

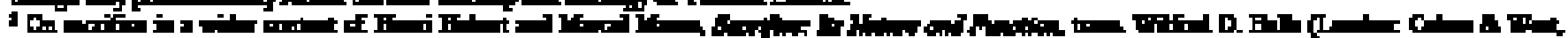

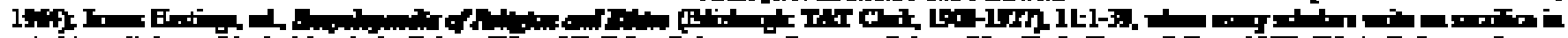
Fin

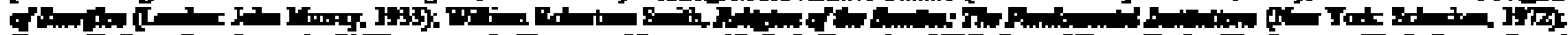

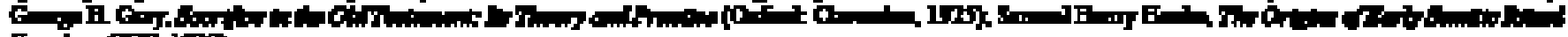
(I)

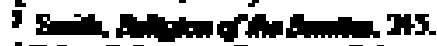

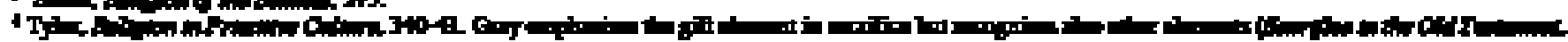

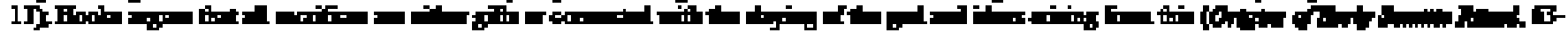

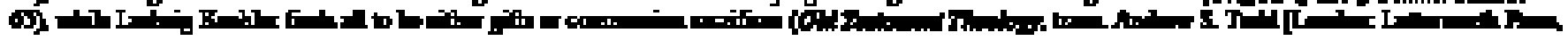
lisis. un.

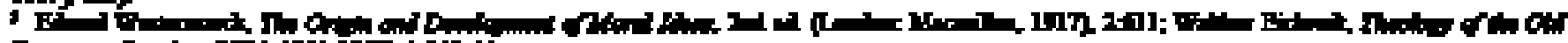
z
} 


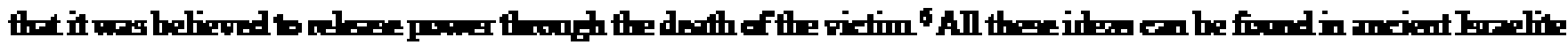

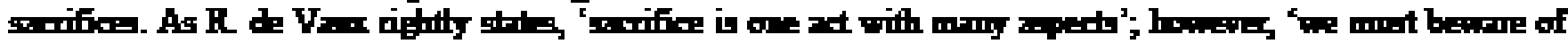
simple arplaritin'?

\section{AGRTD PACES AND ORTLCTS}

Socred Pinere

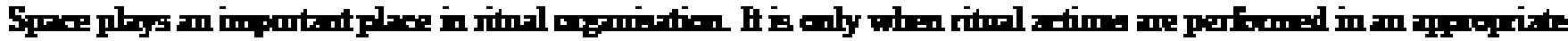

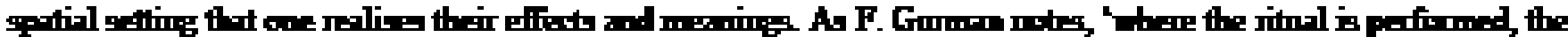

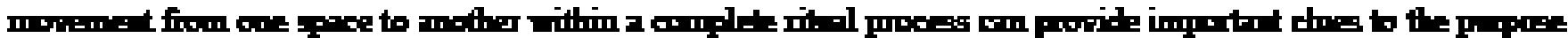

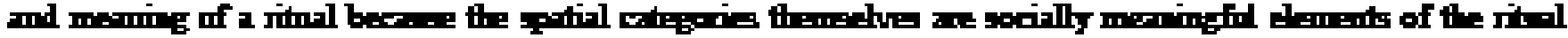

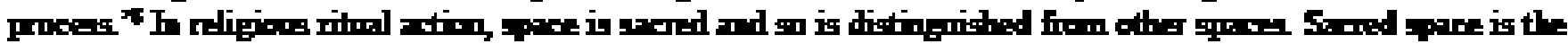

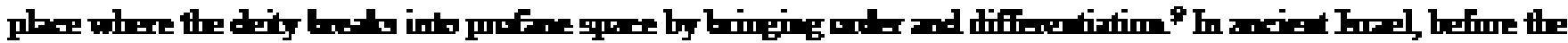

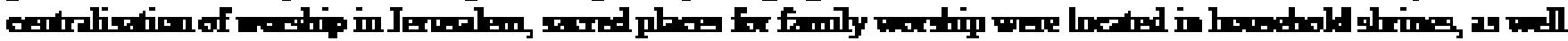

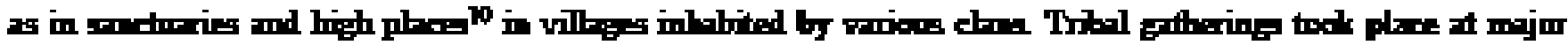

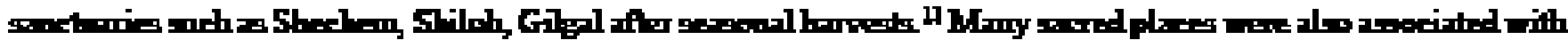
treses, momting ox sping

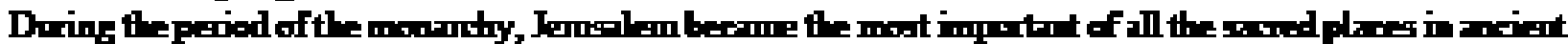

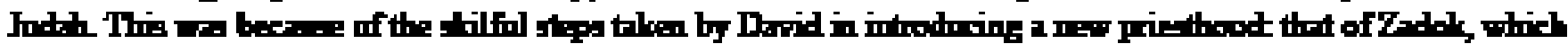

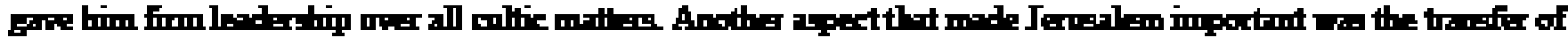

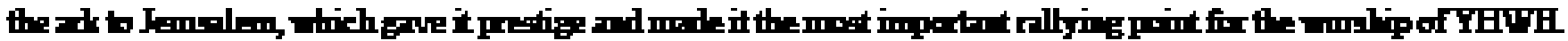

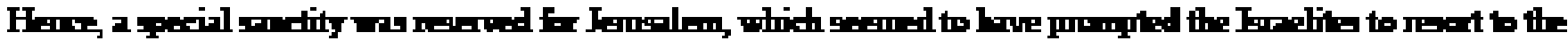

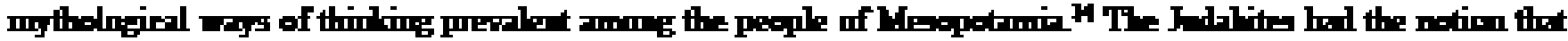

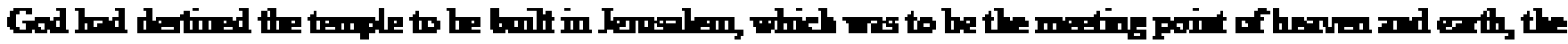

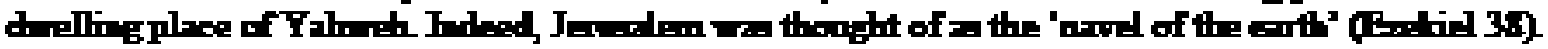

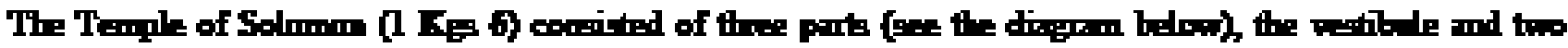

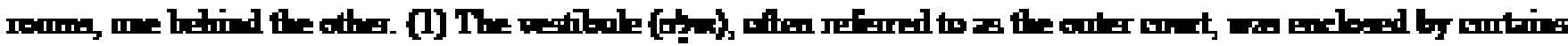

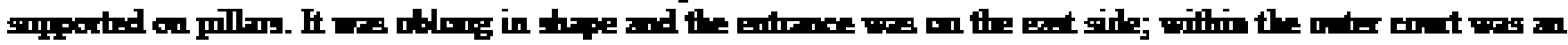

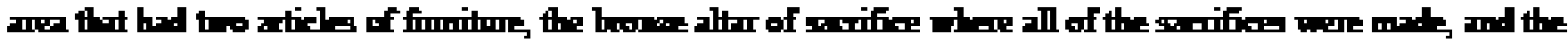

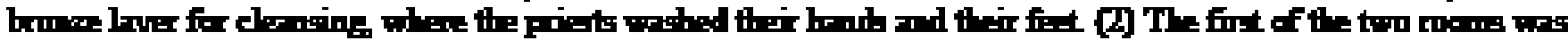

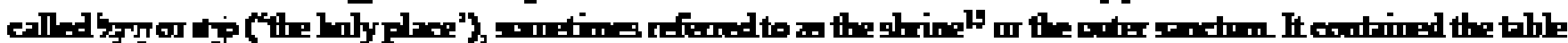

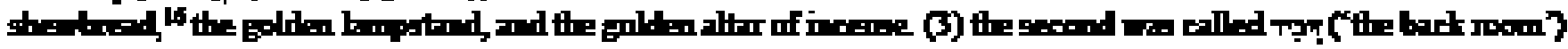

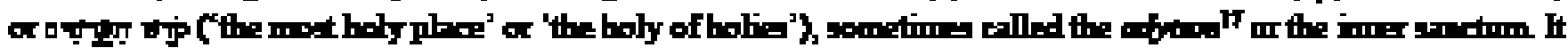

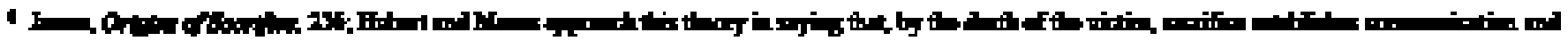
r.

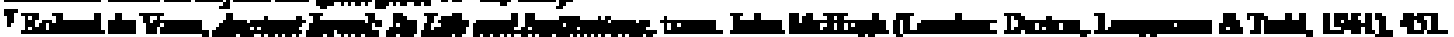

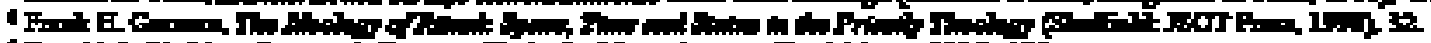

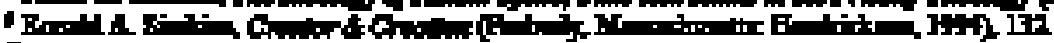

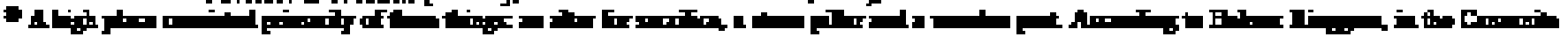

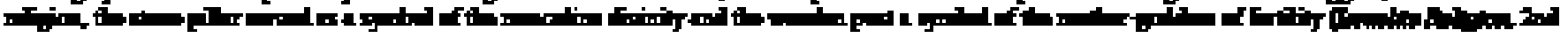

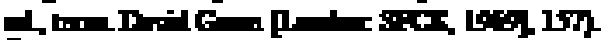

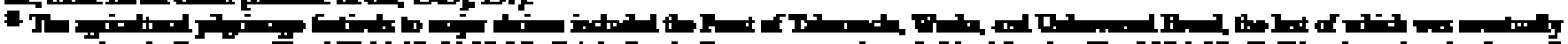

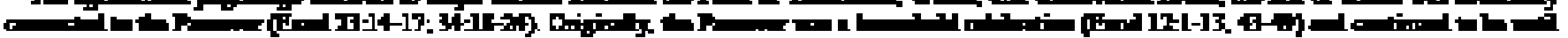

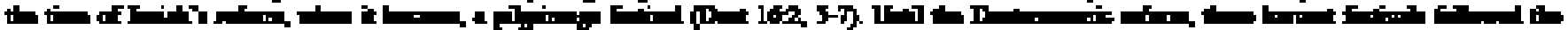

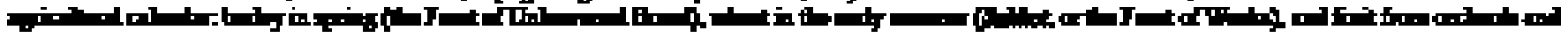

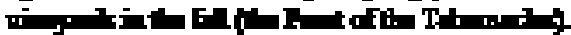

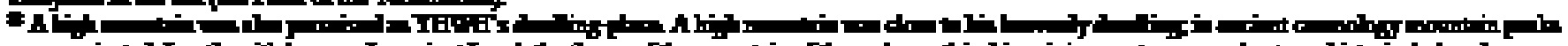
ch i-

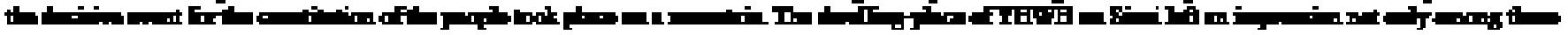

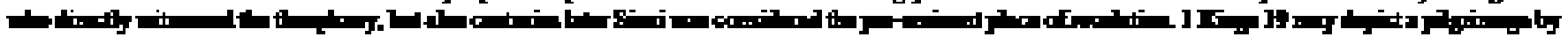

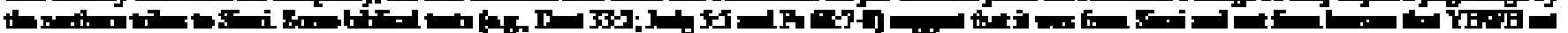

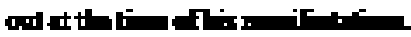

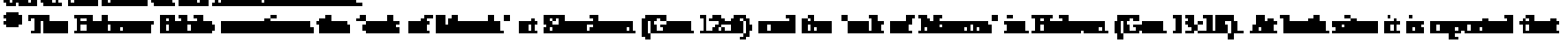
Aln

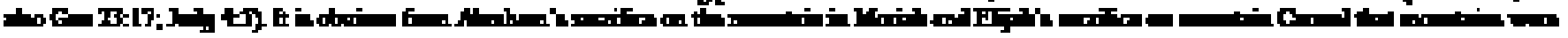
. r l

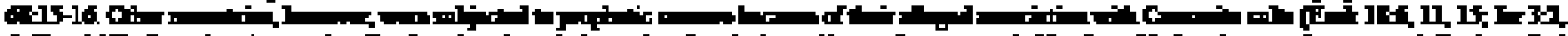

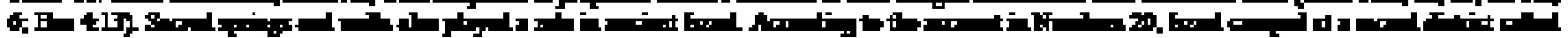

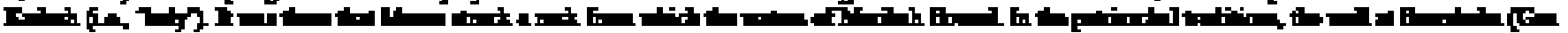

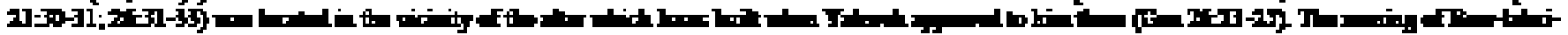

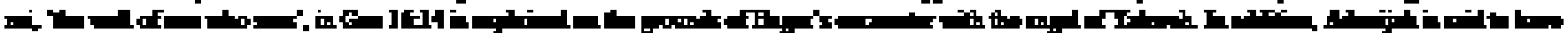

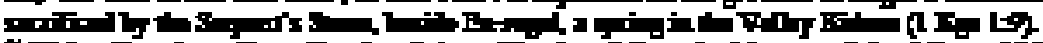

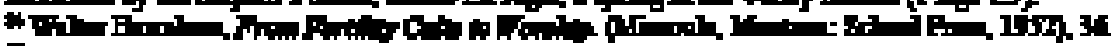

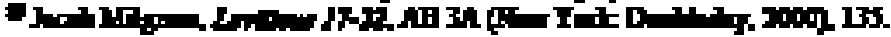

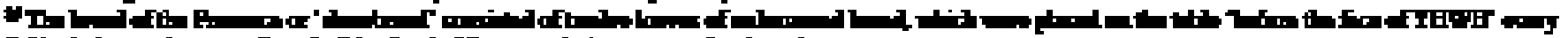

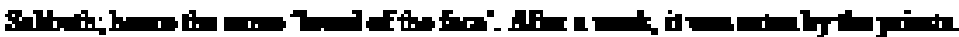

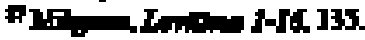




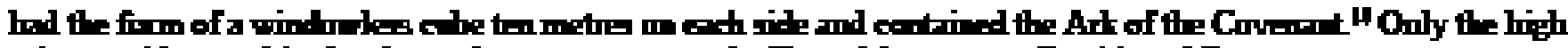

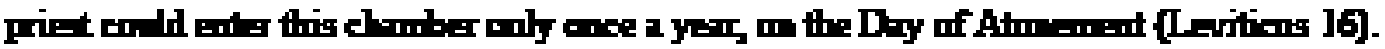

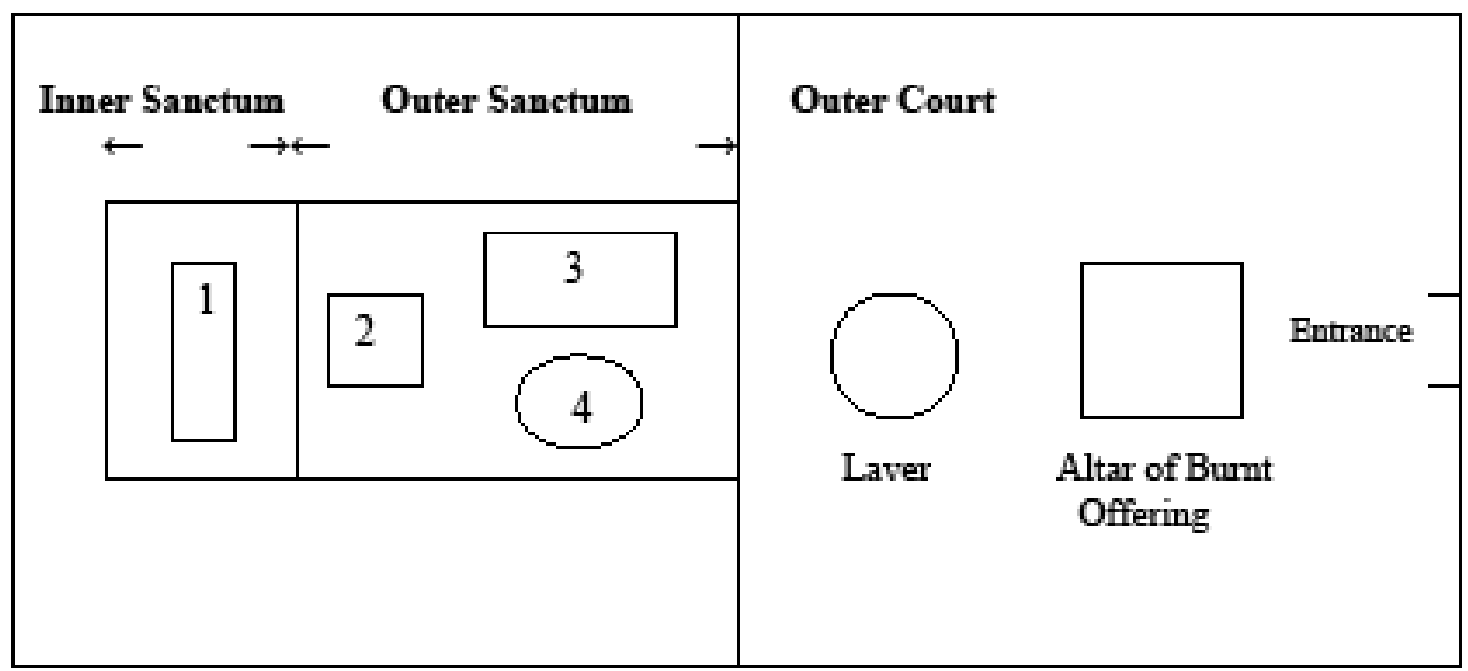

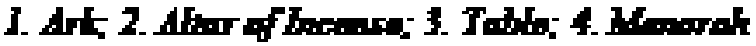

\section{Socred Ohjects}

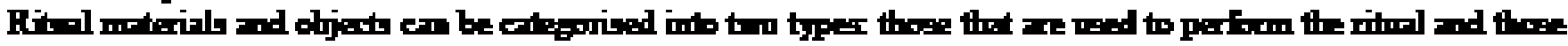

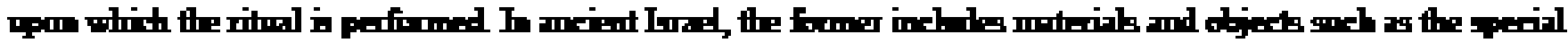

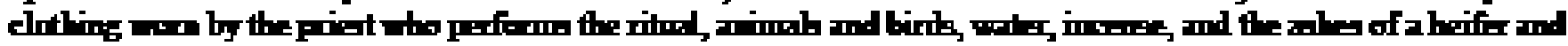

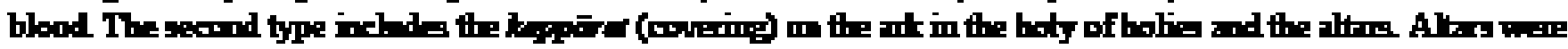

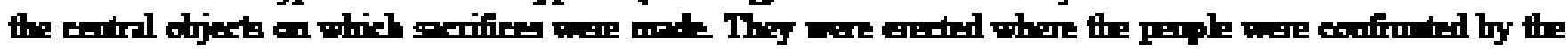

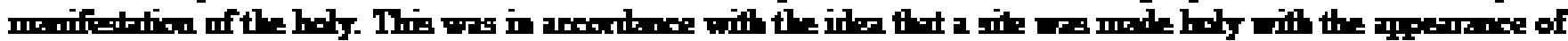

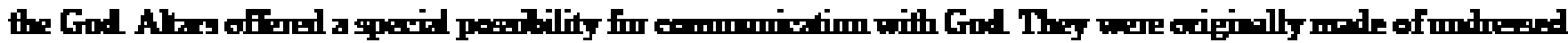
strie variel e.th

\section{SOURCE FOR THE SACRIFCKS}

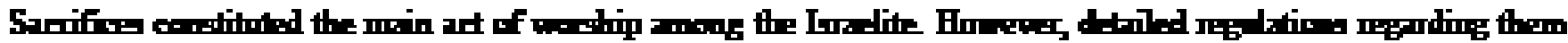

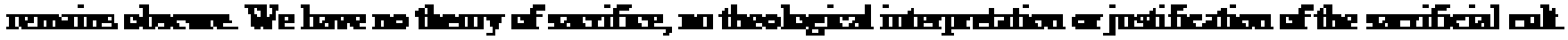

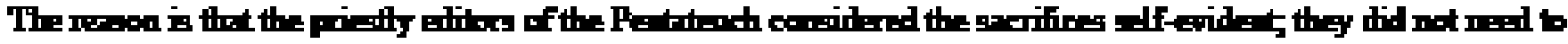

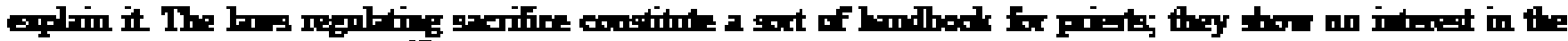

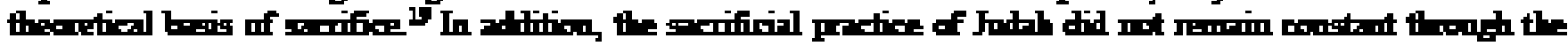

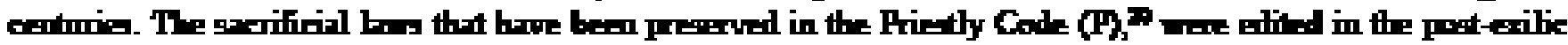

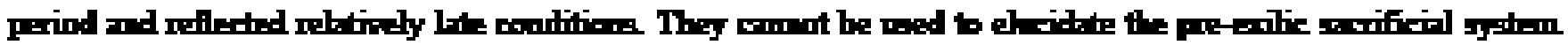

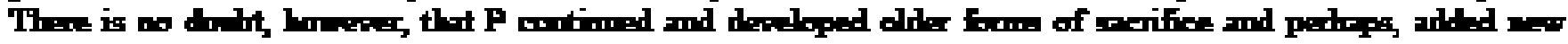

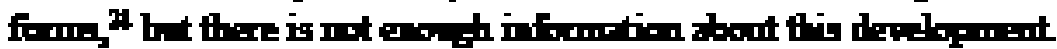

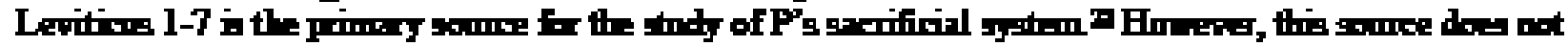

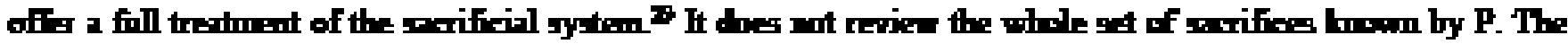

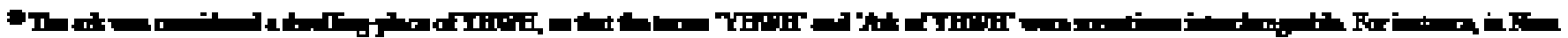

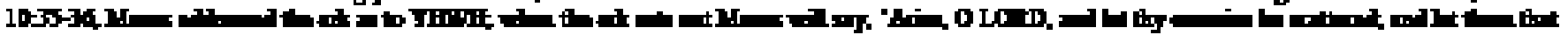

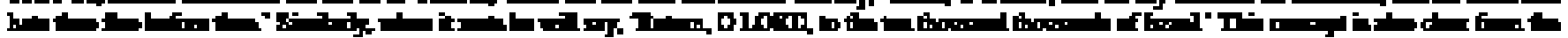

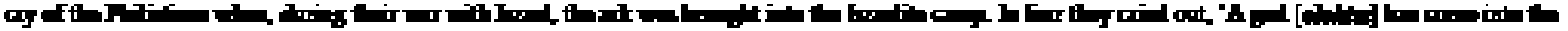

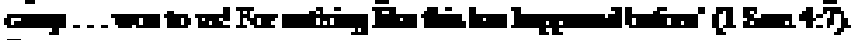

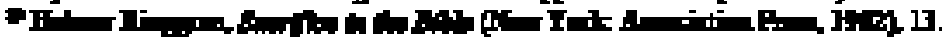

T. F.

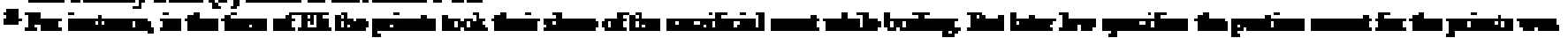
t

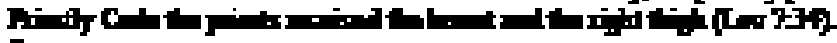

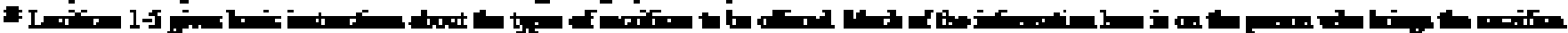

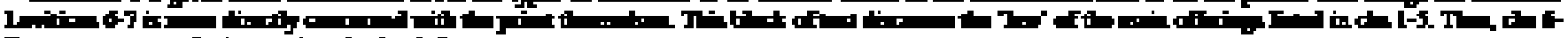

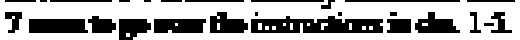

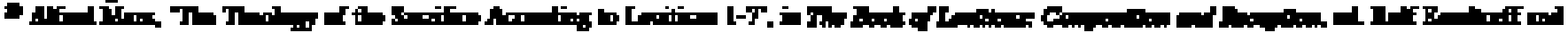

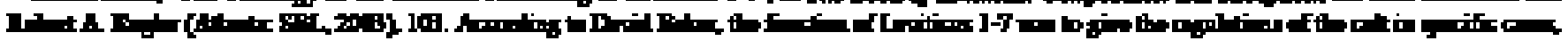

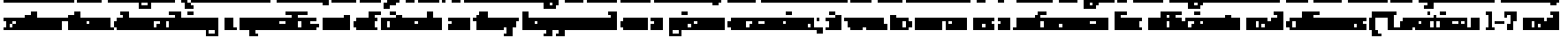

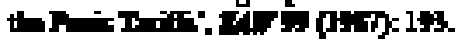




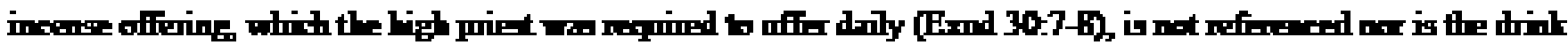

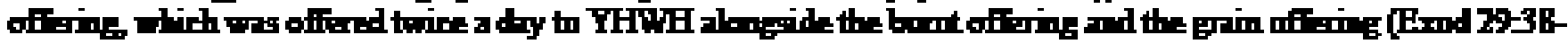

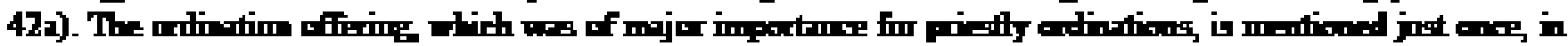

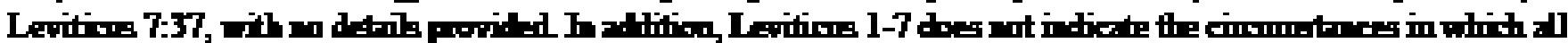

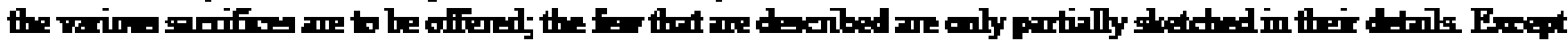

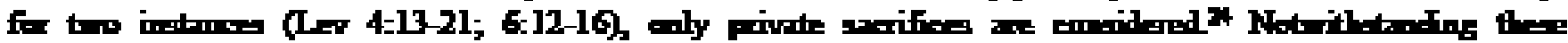

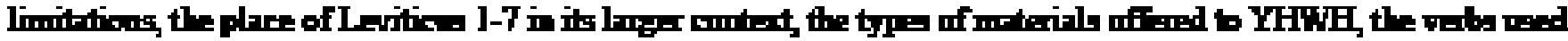

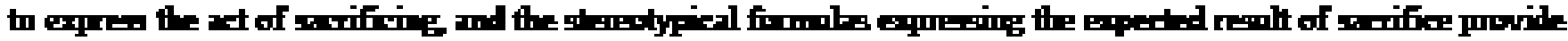

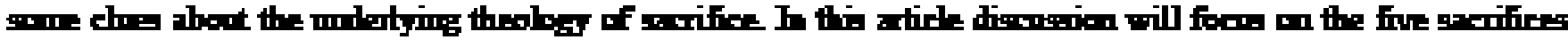
ouflined inlevitions 1-7.

\section{THEFTV SACdIFICXS}

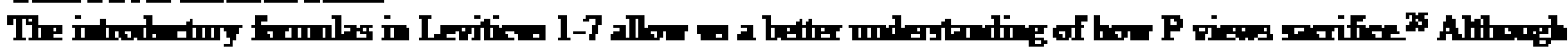

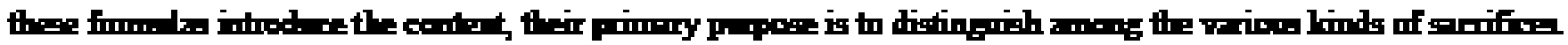

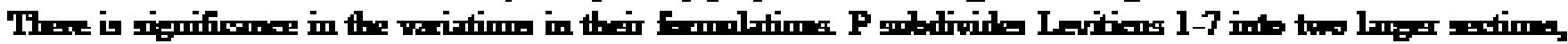
chiplas 1-5 and 6-7.3

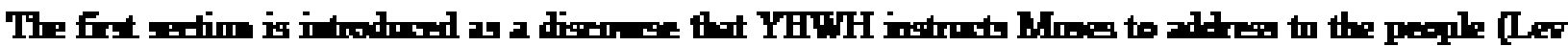

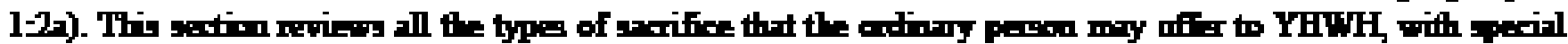

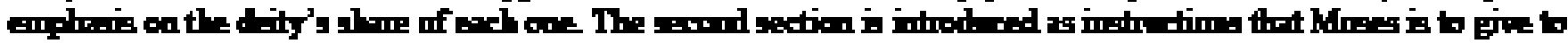

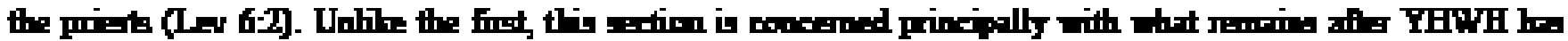

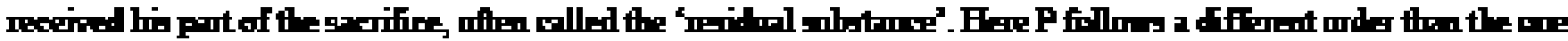
in Lerition ]-5.

\section{The Fire Ofierig (r)}

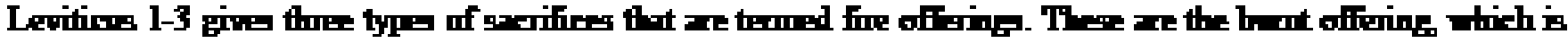

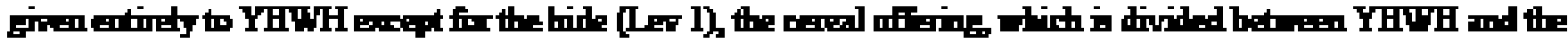

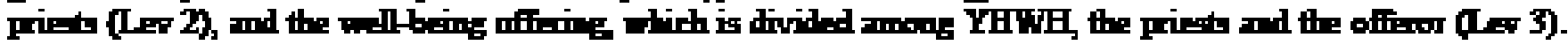
The detrilu of exh of these is descil

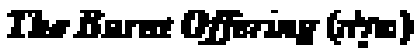

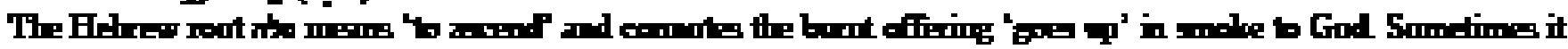

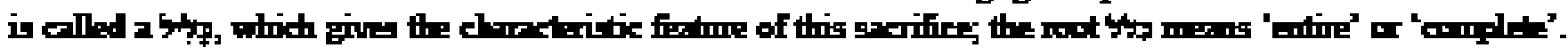

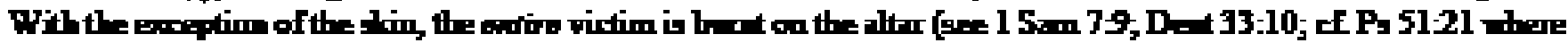

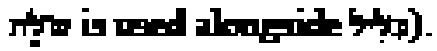

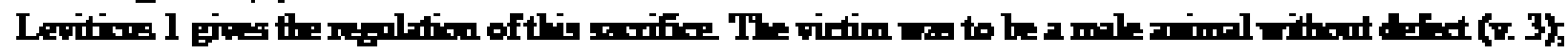

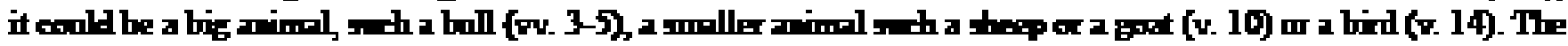

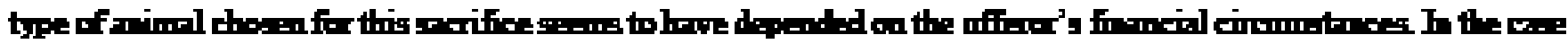

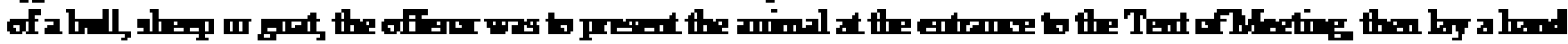

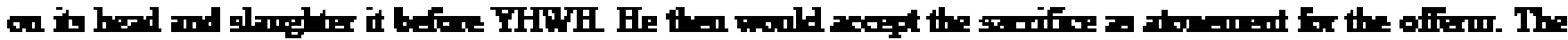

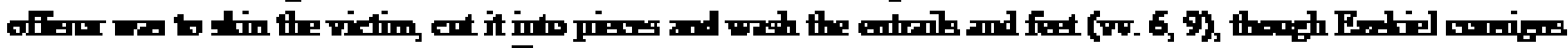

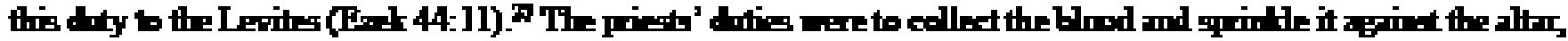

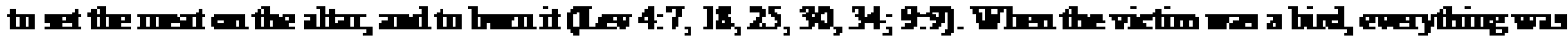

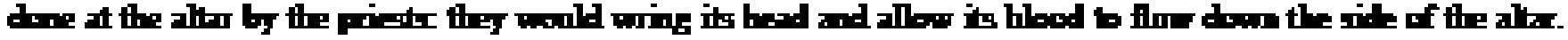

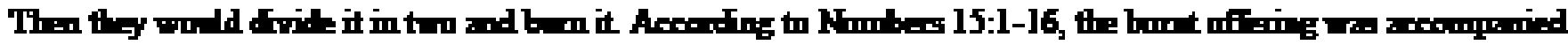

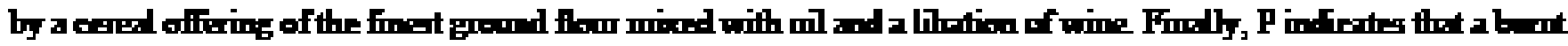

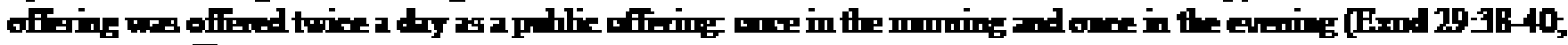
Nom 2B-2-2)

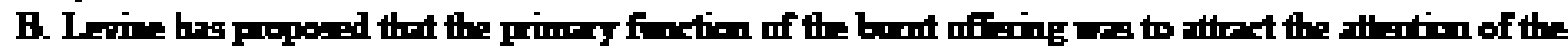

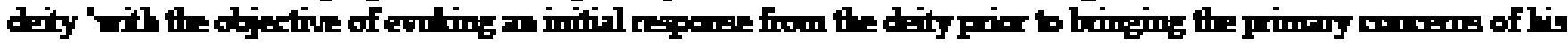

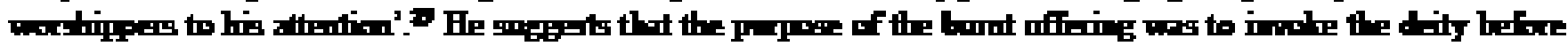

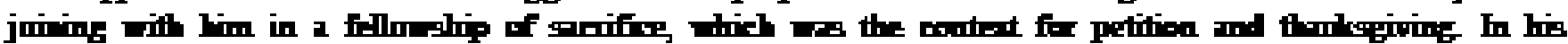

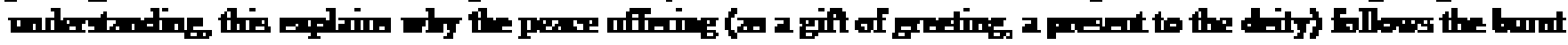

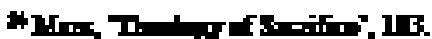

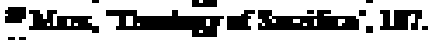

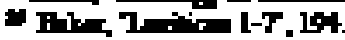

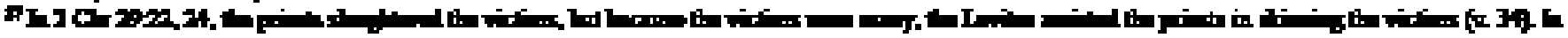

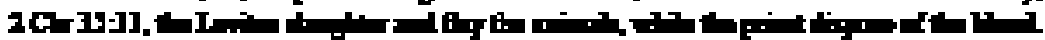

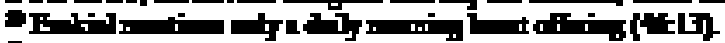

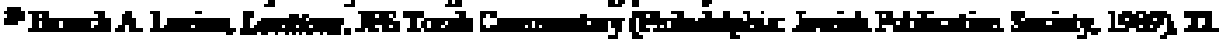




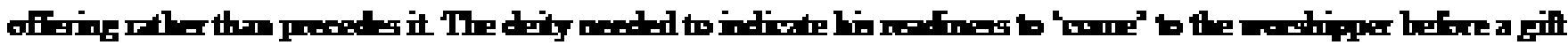

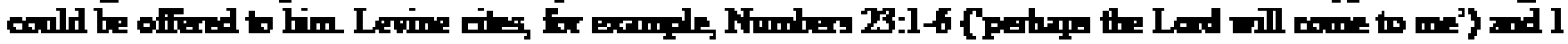
Kinger 18 to bethes his paint

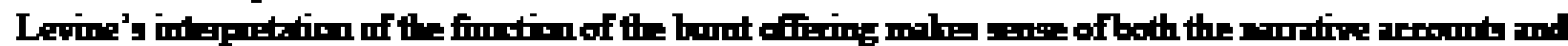

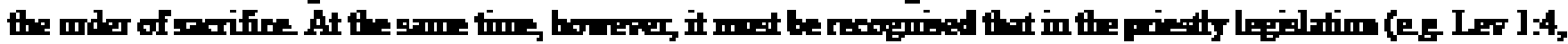

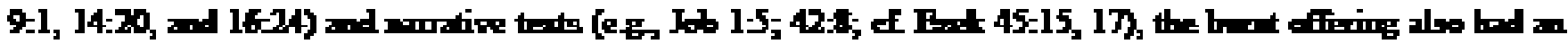

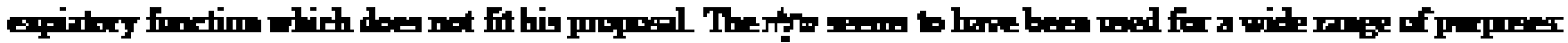

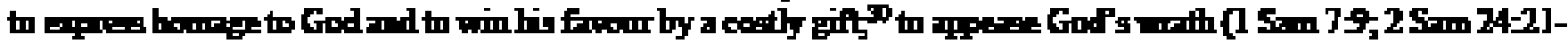

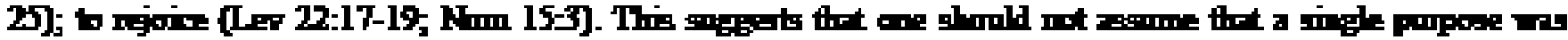

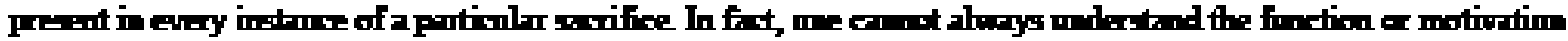
of this garifine ${ }^{3}$

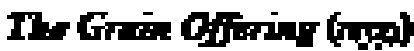

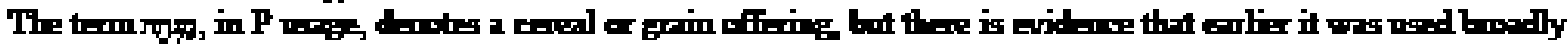

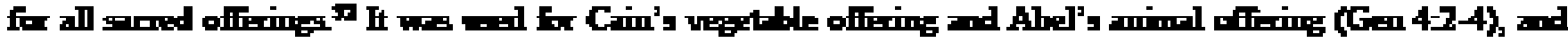

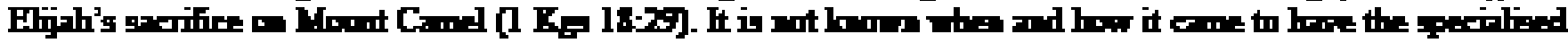
meraing is $P$.

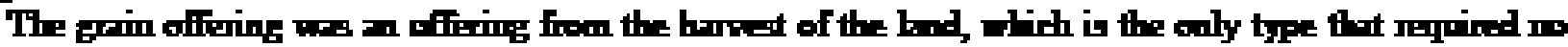

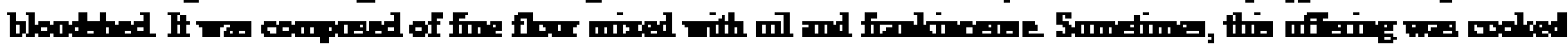

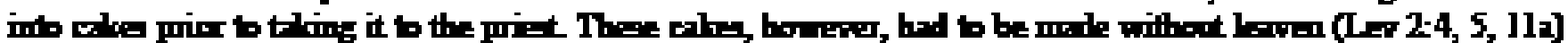

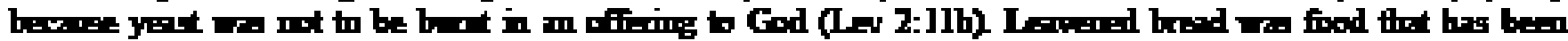

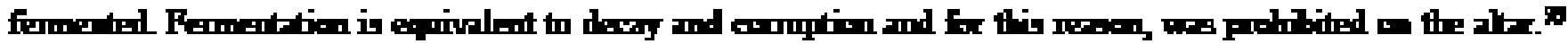

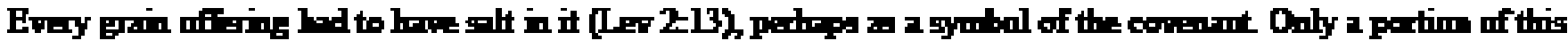

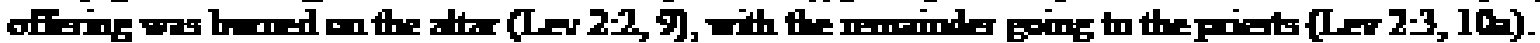

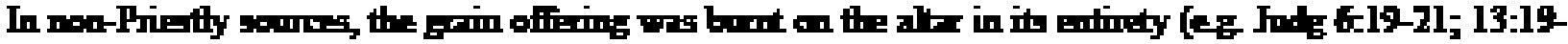

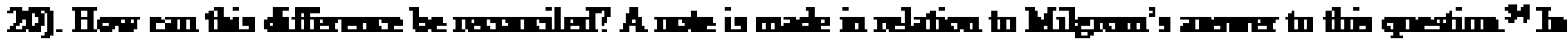

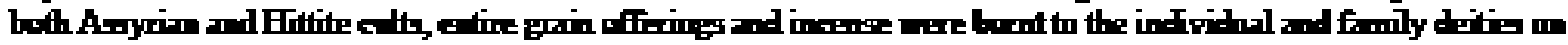

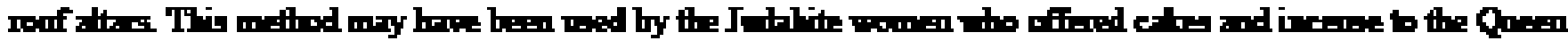

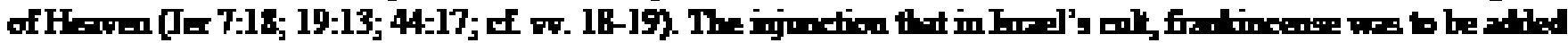

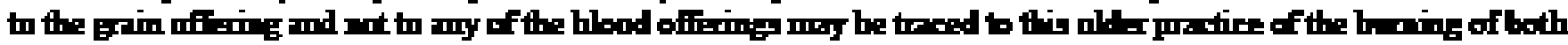

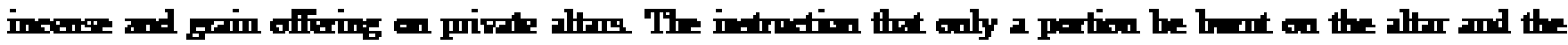

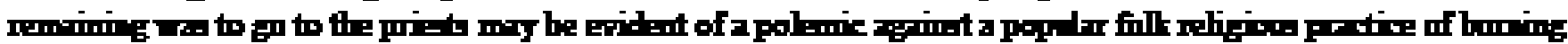

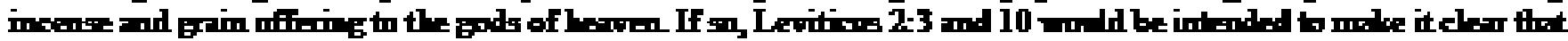

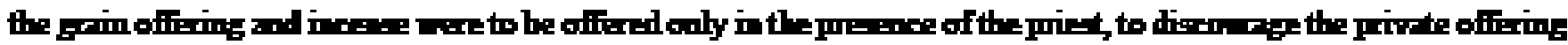
of grin and incieve

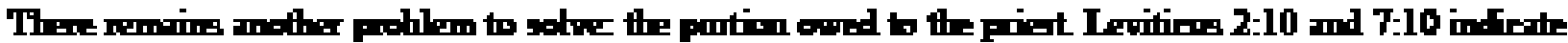

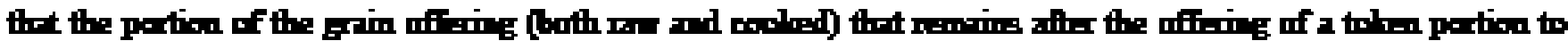

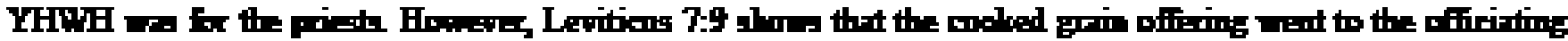

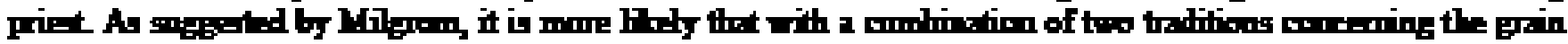

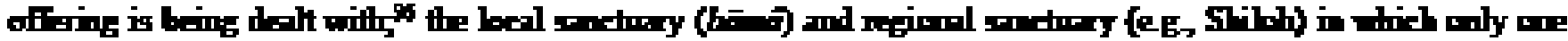

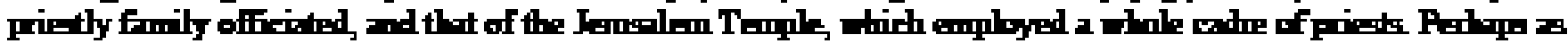

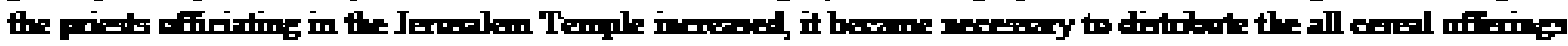

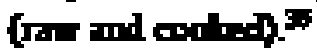

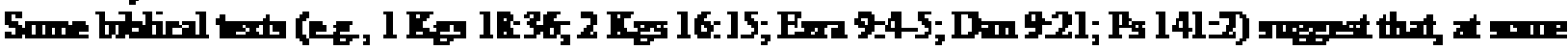

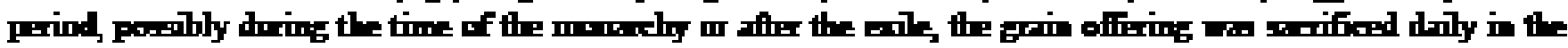

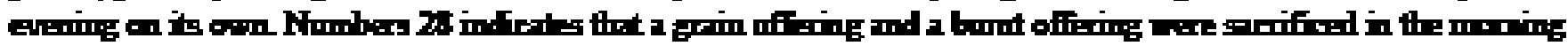
and the evering.

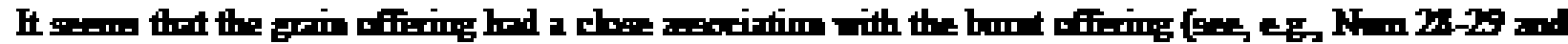

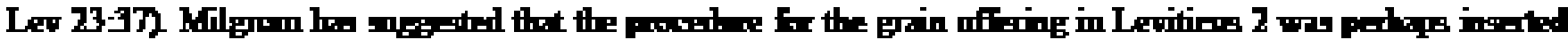

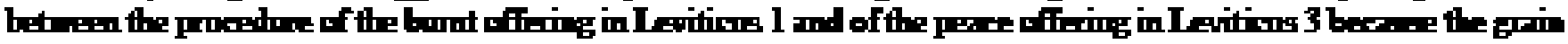

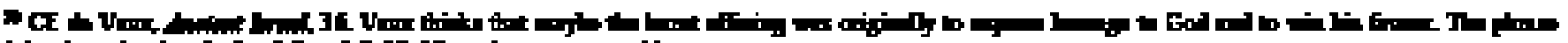

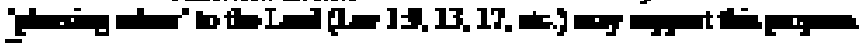

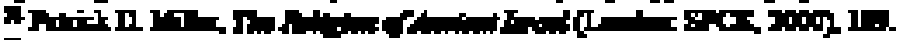

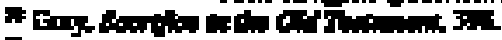

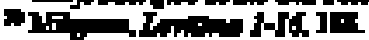

Har

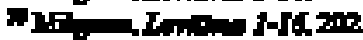

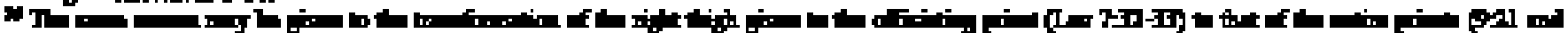
$10-15$
} 


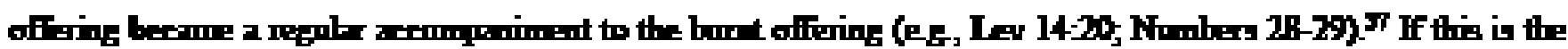

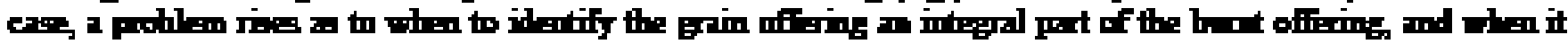

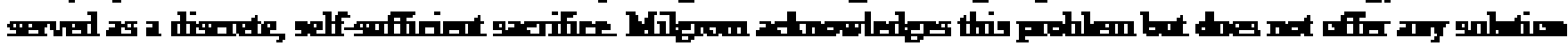
of hil $\cosh ^{3}$

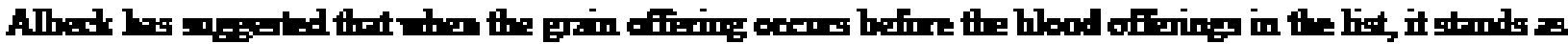
a dicus r.

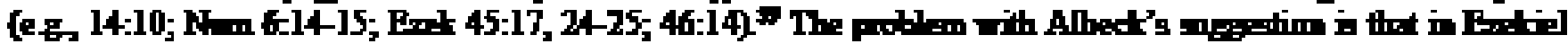

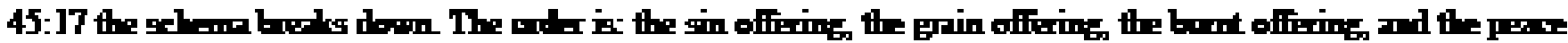

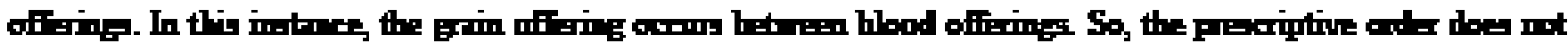

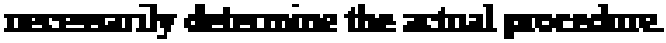

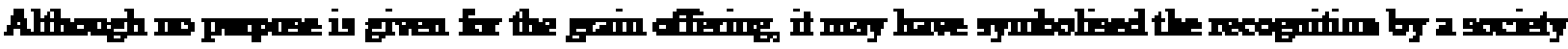

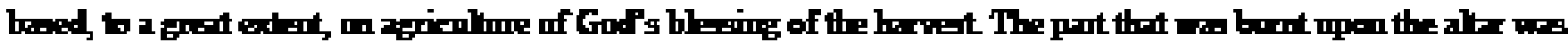

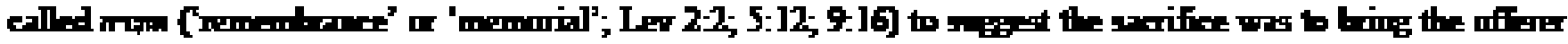

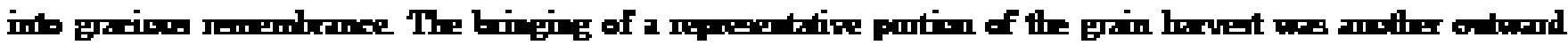

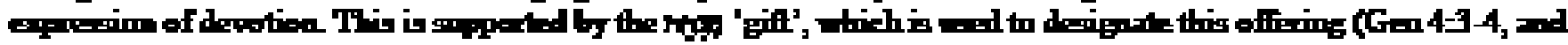

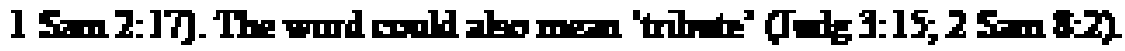

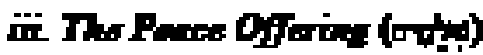

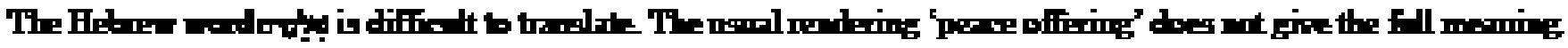

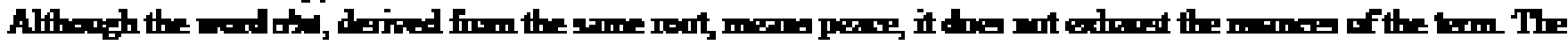

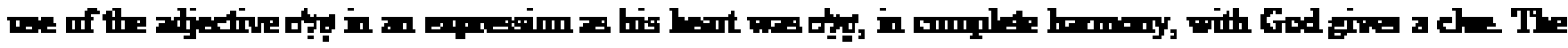

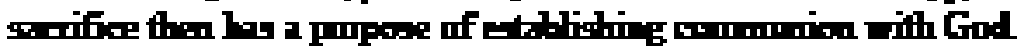

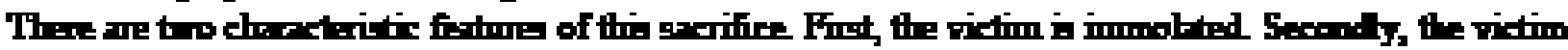
is ghe betwen YHWH, the pied, and the uf

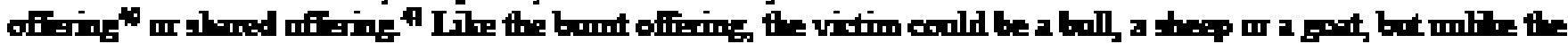

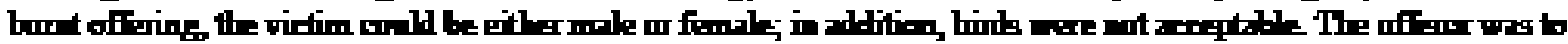

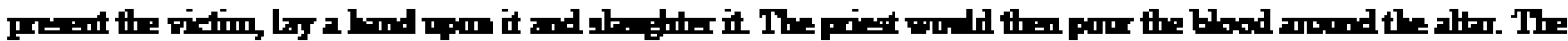

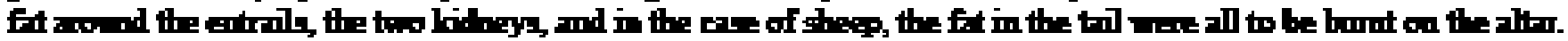

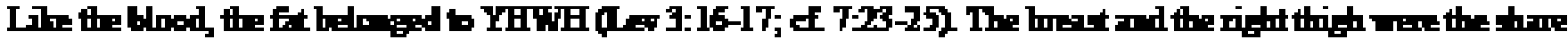

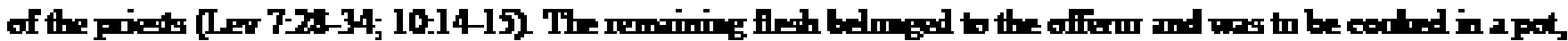

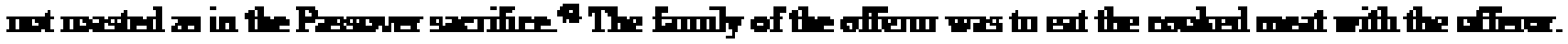

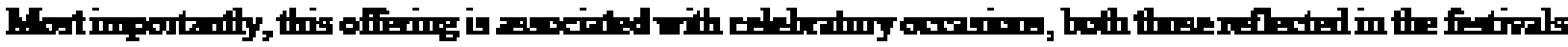

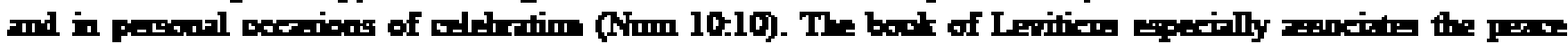

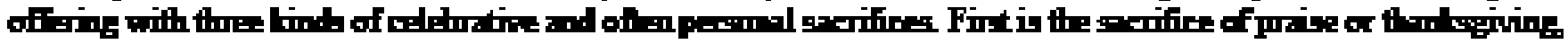

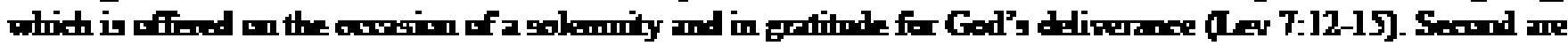

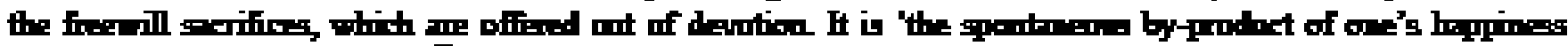

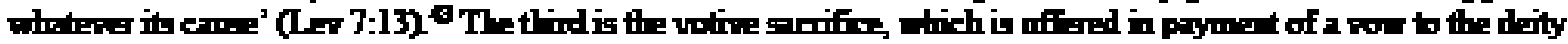
to same the dity's help (In: 7:13)

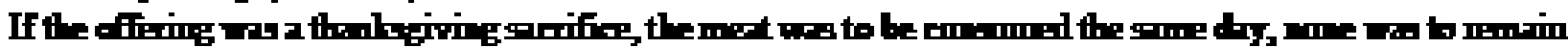

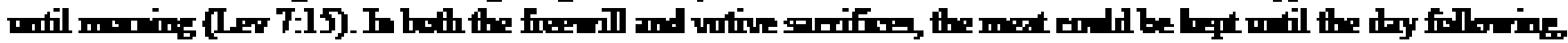

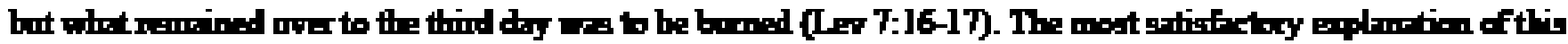

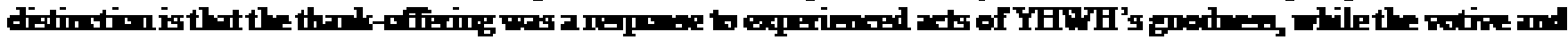

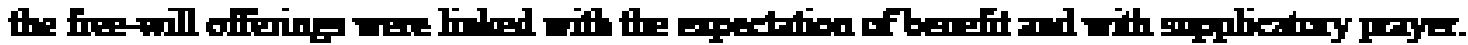

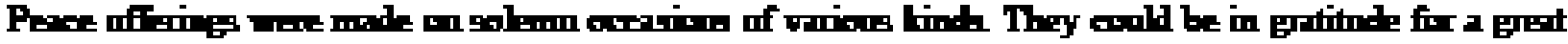

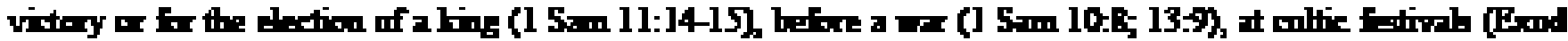

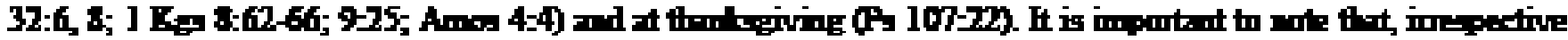

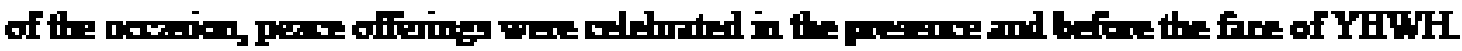

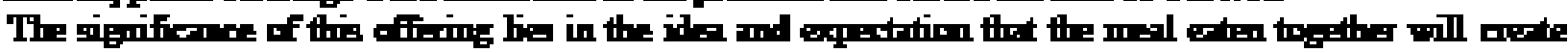

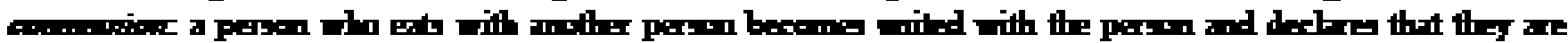

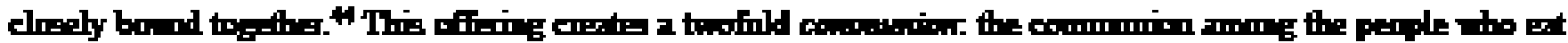

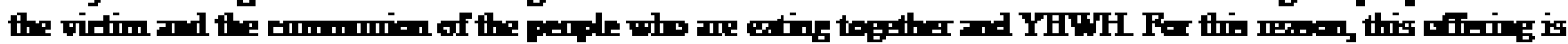

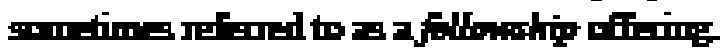

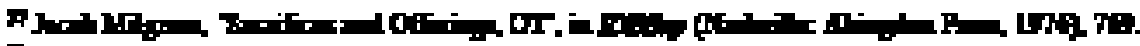

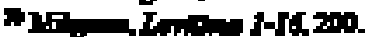

mF

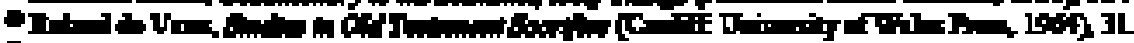

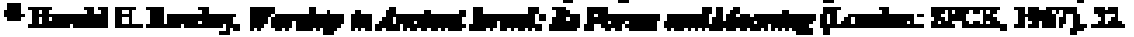

:Fen

-

HF-I F 


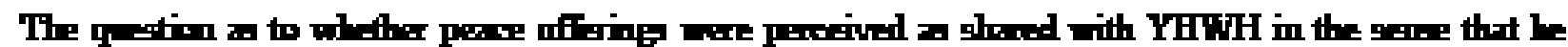

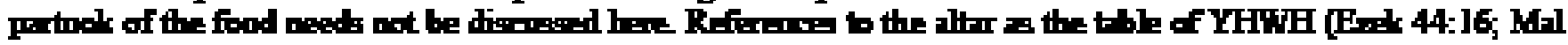

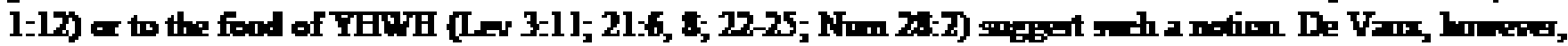

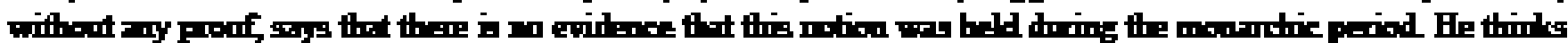

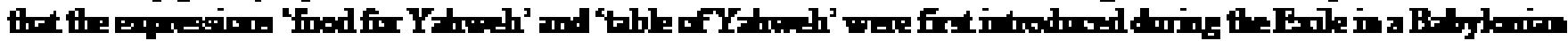

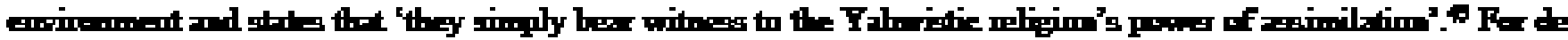

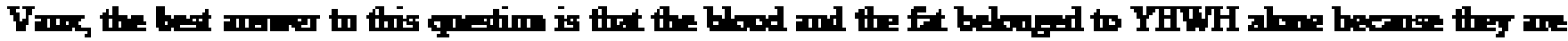

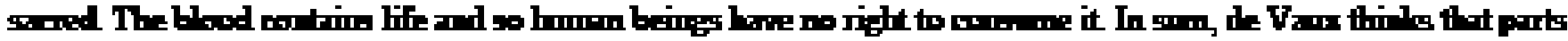

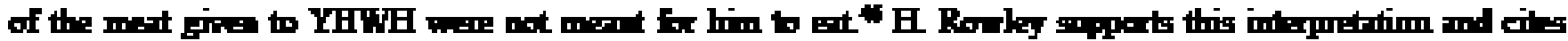

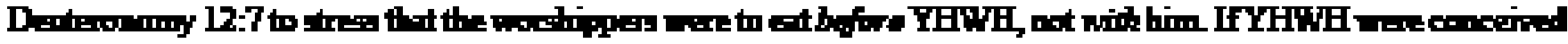

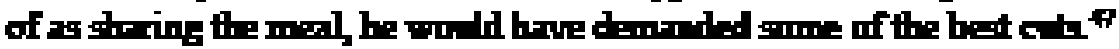

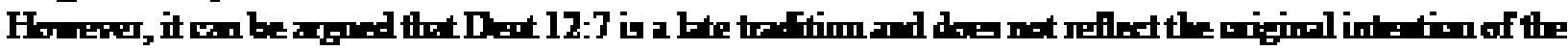

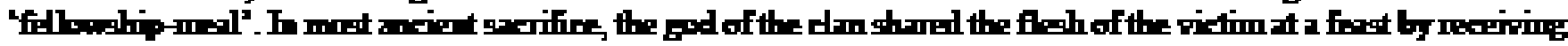

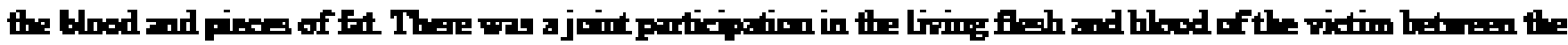

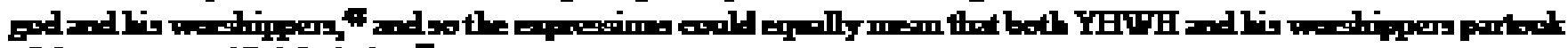
of the r.me arrificil virim "

\section{Twe 드 Ofiring (- r)}

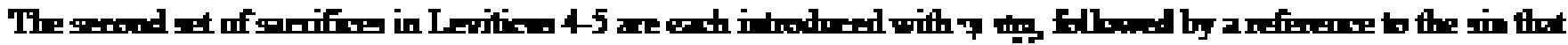

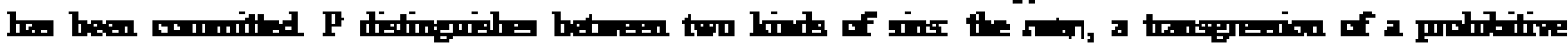

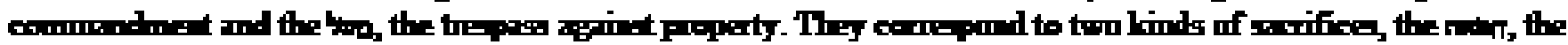

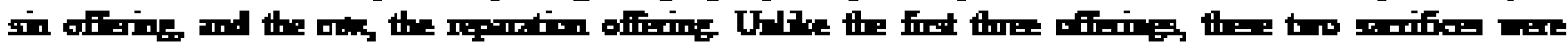

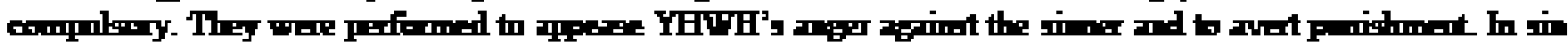

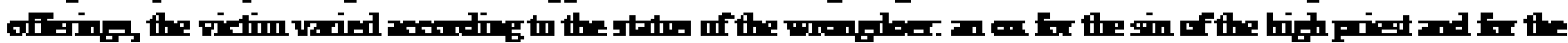

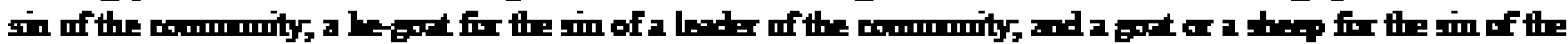

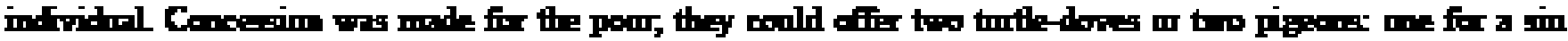

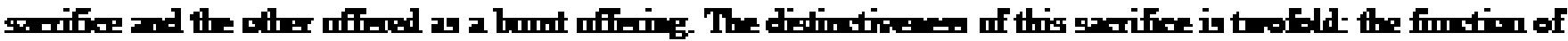

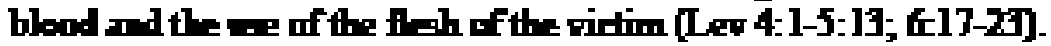

\section{Sin oporin (n)}

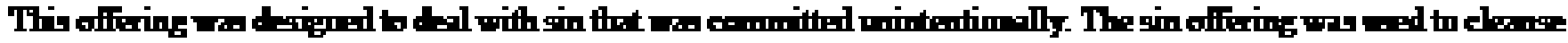

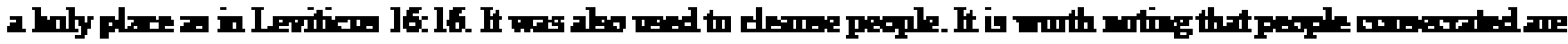

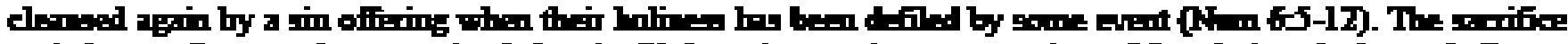

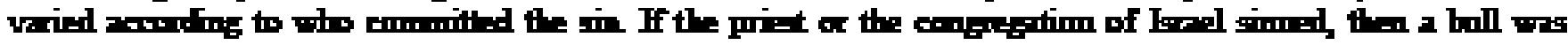

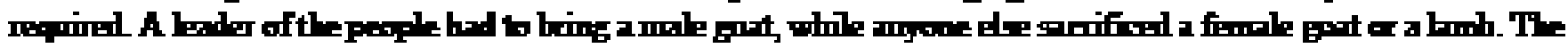

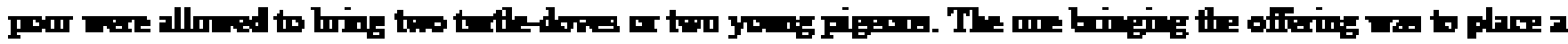

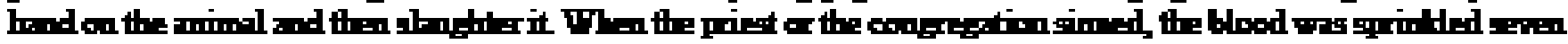

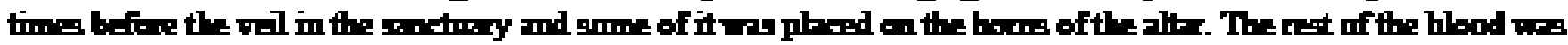

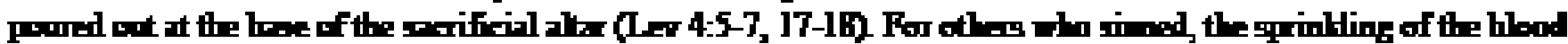

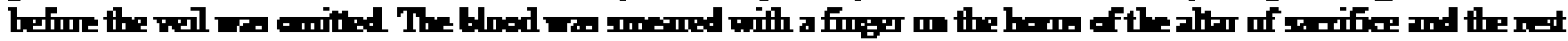

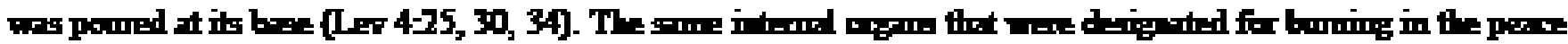

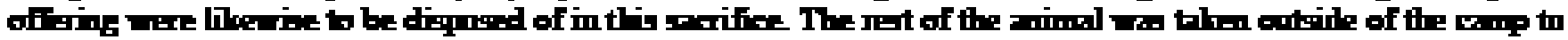

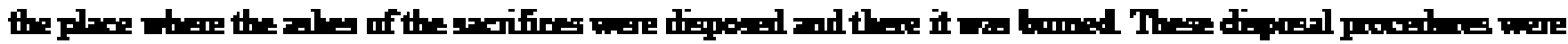

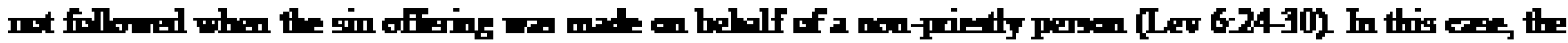
Firt wa allmaed to ext anme of the meat

\section{The Grols Ofjoin (f)}

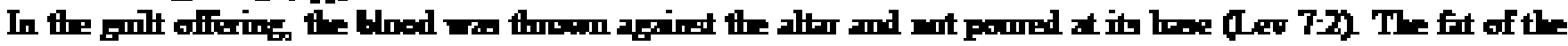

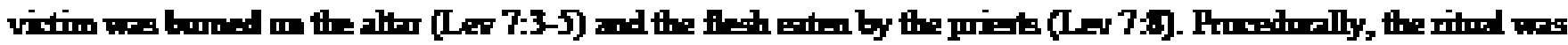

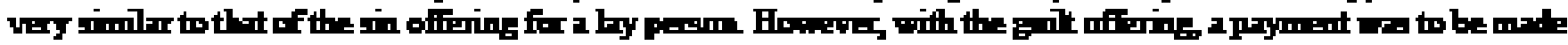

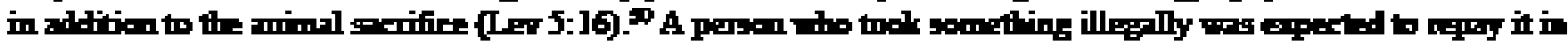

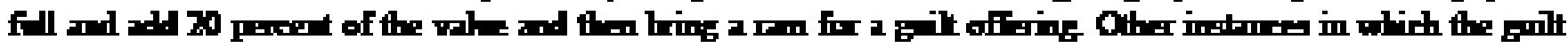

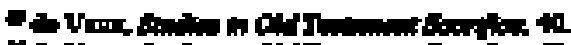

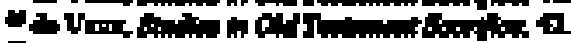

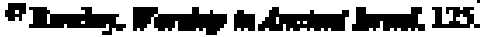

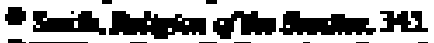

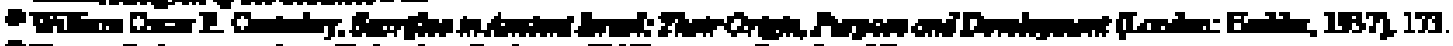

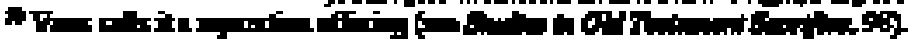




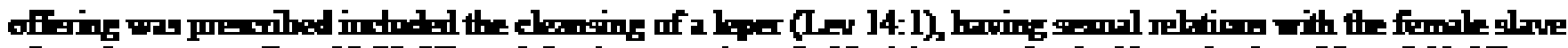

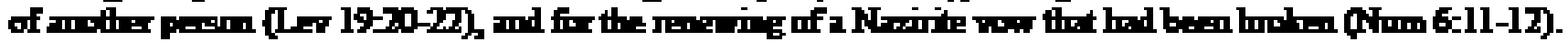

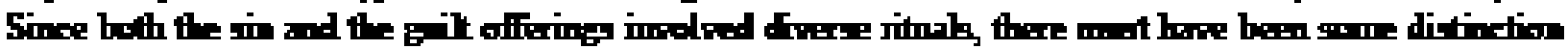

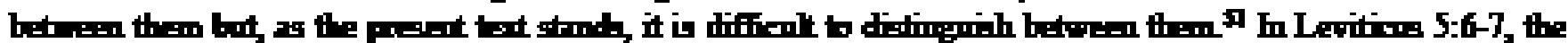

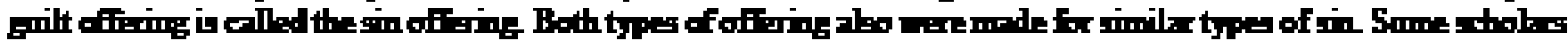

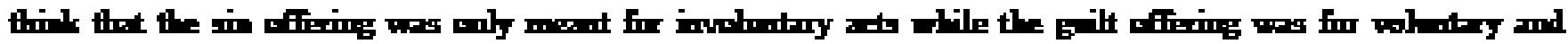

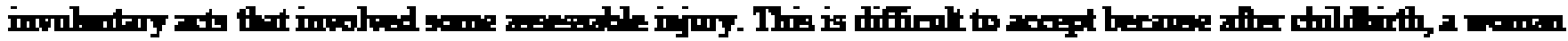

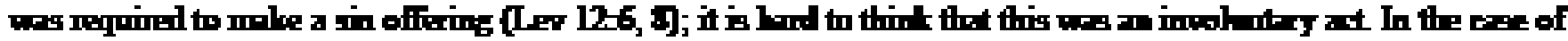

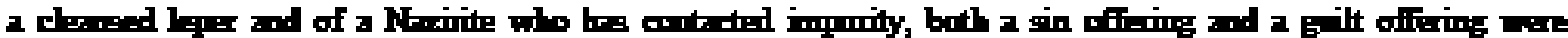

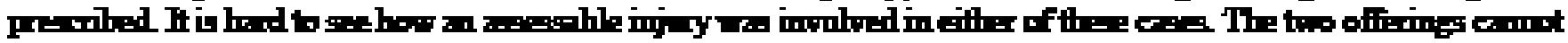

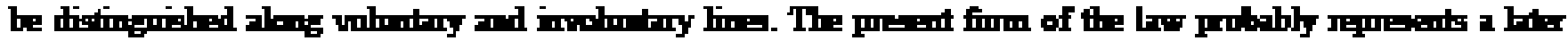

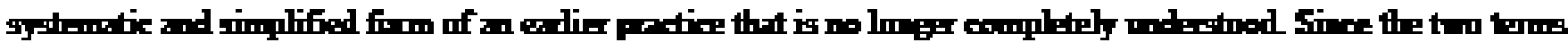

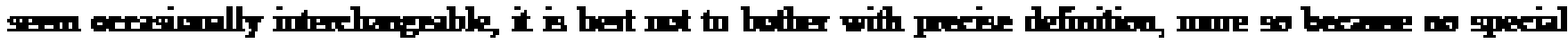

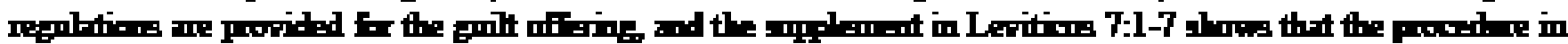
both ore rea enentilly the rmes

\section{THE ROIS OF BLOOD IN SACHTHCE}

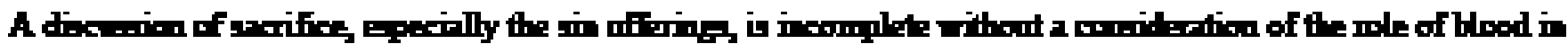

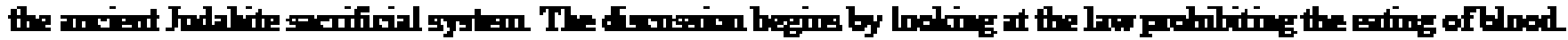

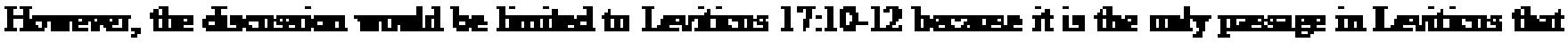

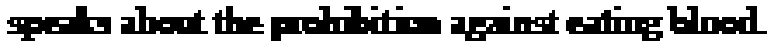

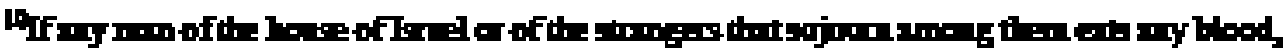

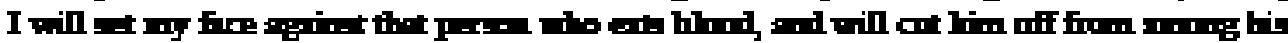

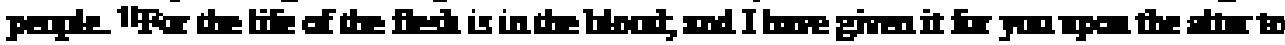

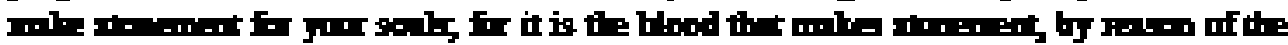

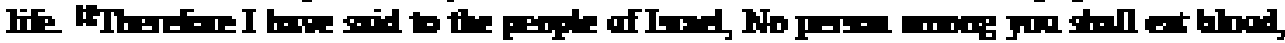

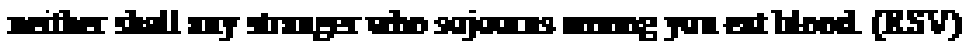

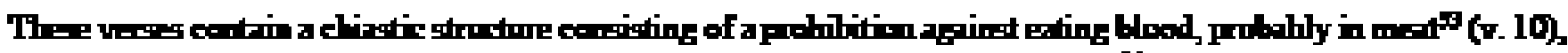

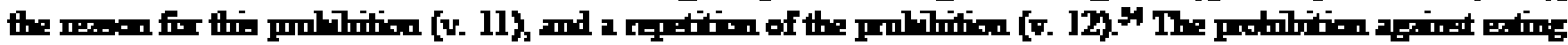

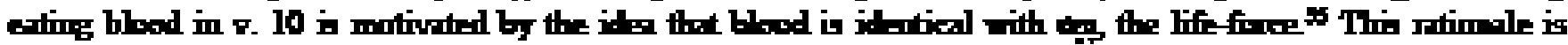

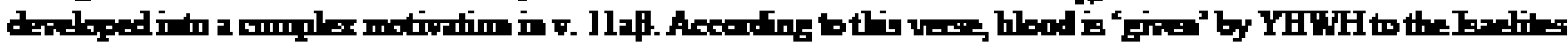

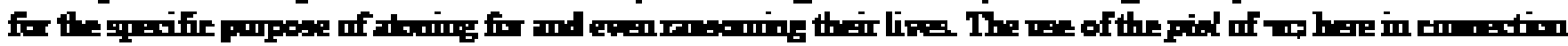

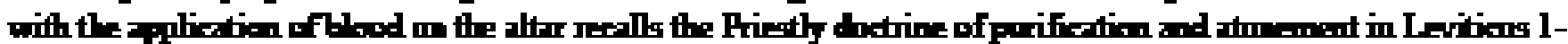

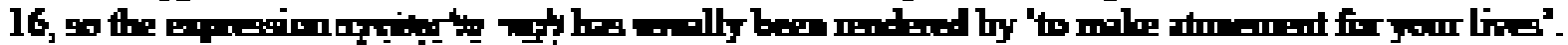

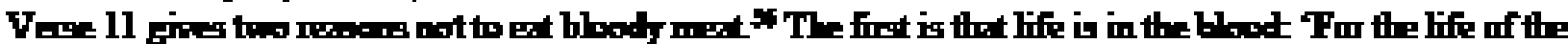
fleh in is the blnod. . .' (v. llan) The iden belind this is that sing the blnod antring the life of the a imal, and

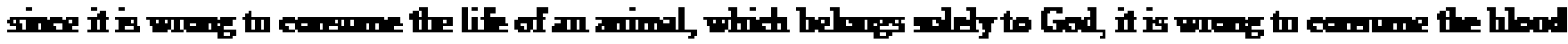

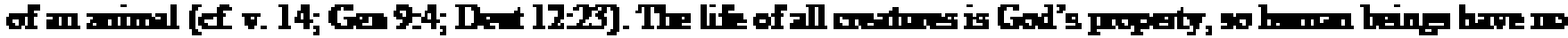

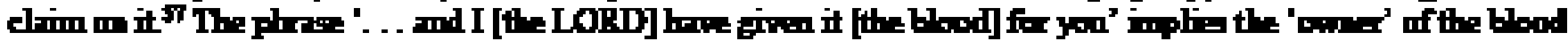

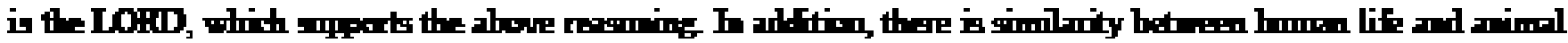

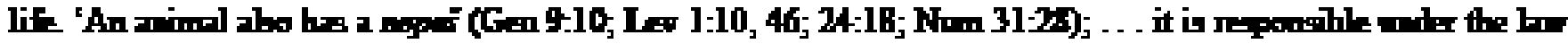

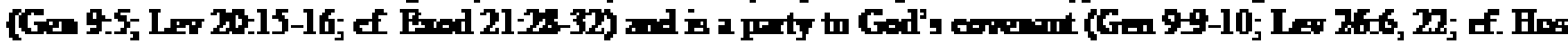

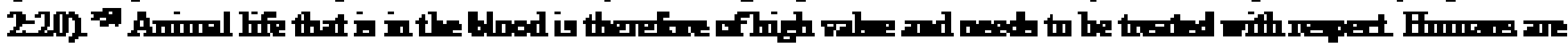

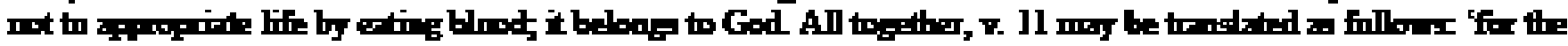

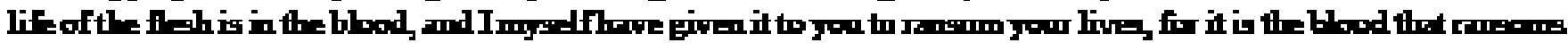

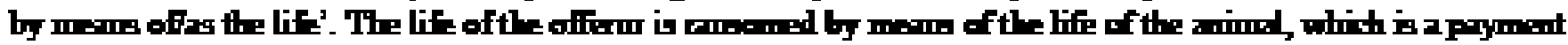
to tive the uffinded pacty, YHWH, ba apered.

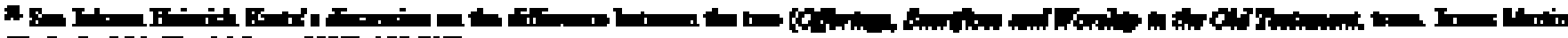

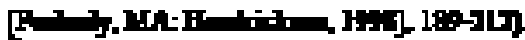

*rice

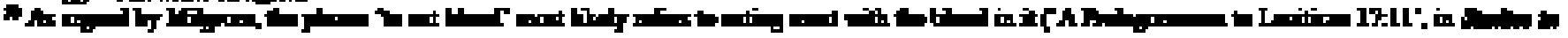

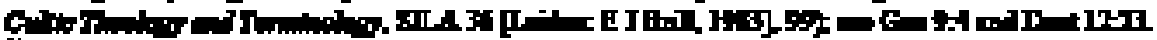

*1.

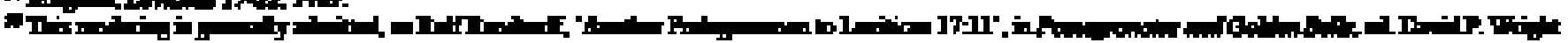

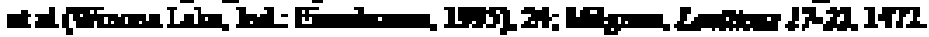

*IE

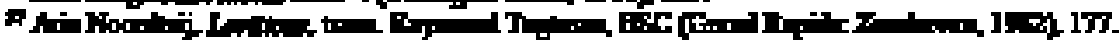

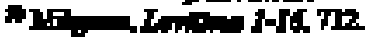




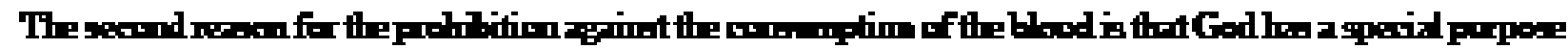

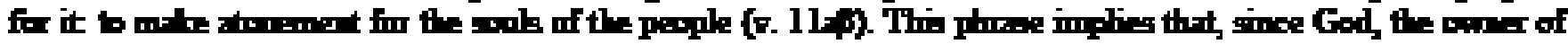

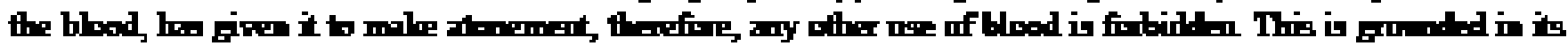

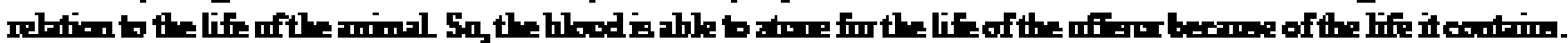

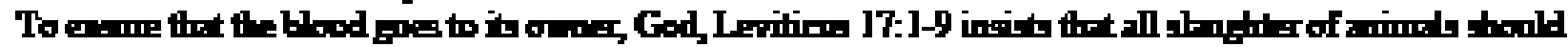

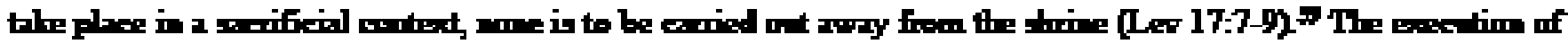

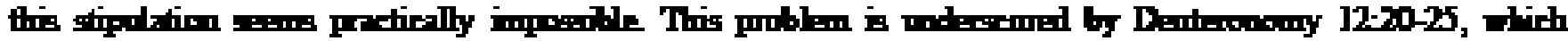

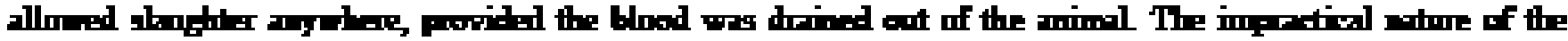

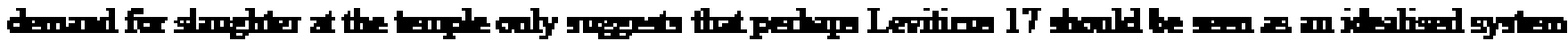

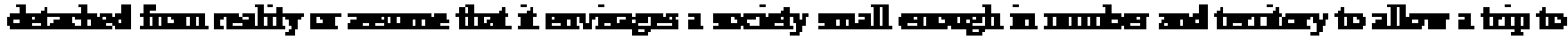

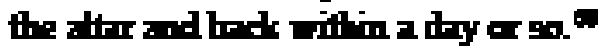

\section{CONCLdGION}

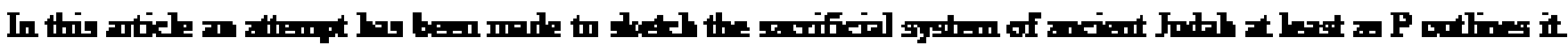

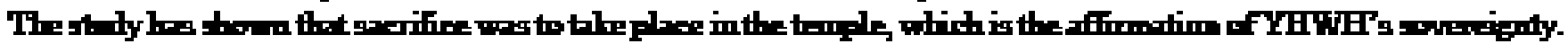

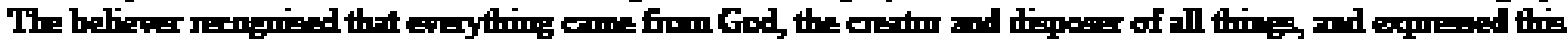

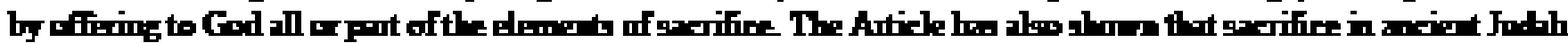

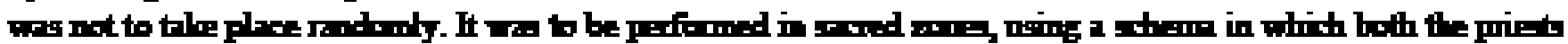

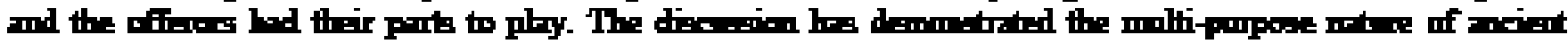

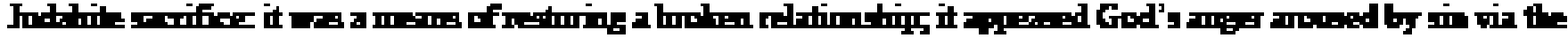

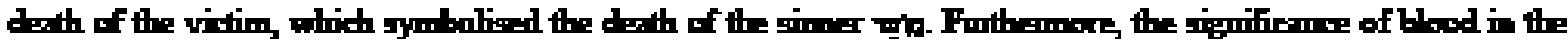

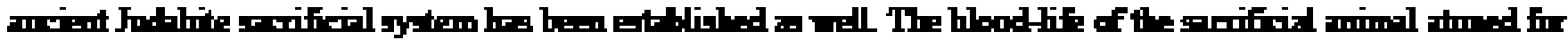

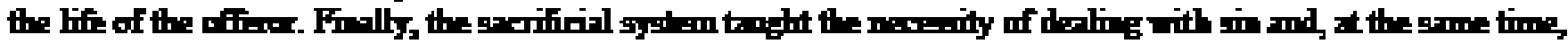

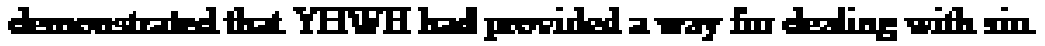

\section{ABOUT AUIFOR}

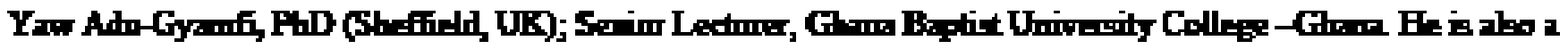

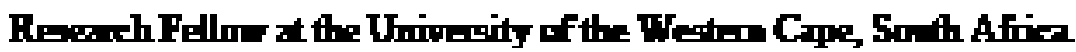

\section{BIPI IOCEAPHY}

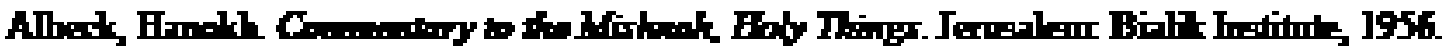

Bder, Davil 'Levitime 1-7 and the Puir Taiff'. ZAF 99 (1987): 18:-197.

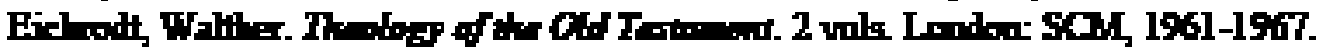

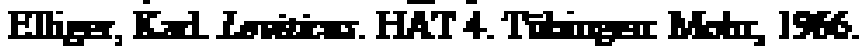

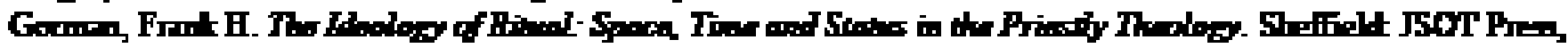
1990.

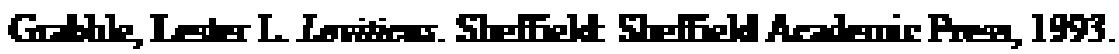

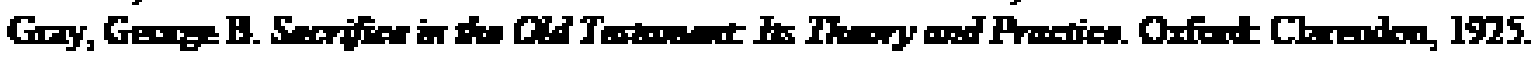

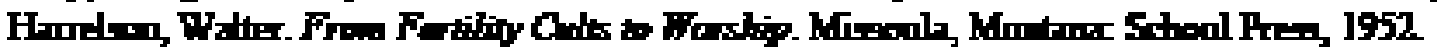

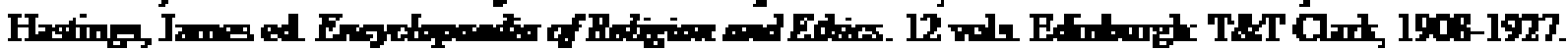

Hendel, Ronld S. 'Sanifir ag a Cukmal System'. ZAW 101 (1969) 366-390.

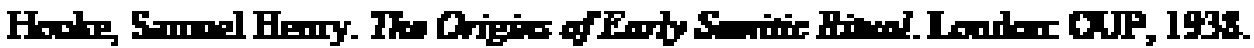

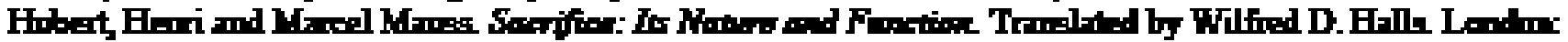
Colen \& Wet, 1964.

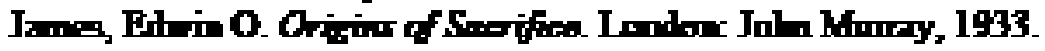

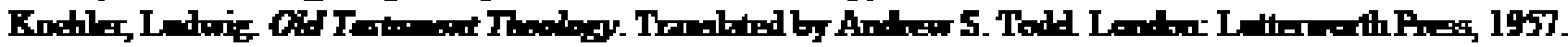

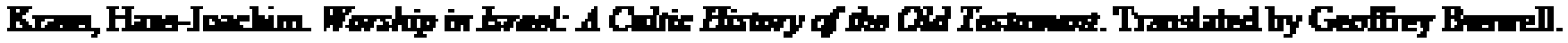
Ristmond, Vireinir Knm, 1962.

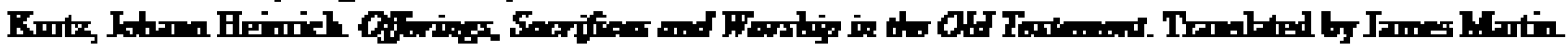
Peabody, MA: Entridem, 1998.

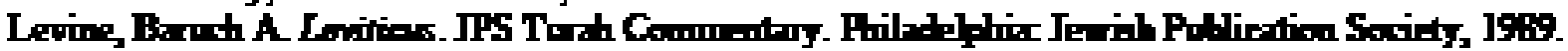

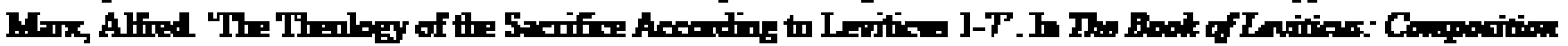

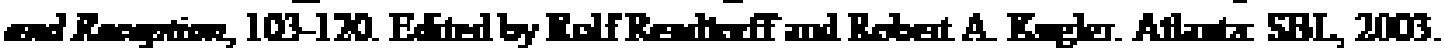

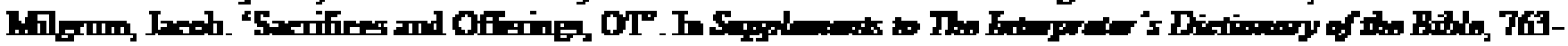

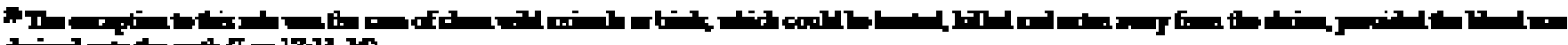

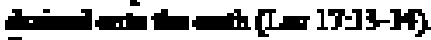

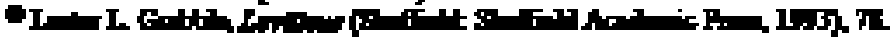


T7. Keshoille Abinglon Pres, 1976.

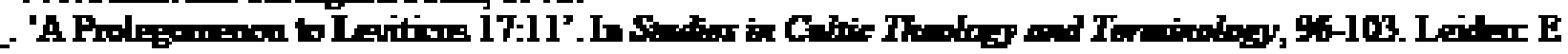
J Brill, 1983.

Ifritits I-I6. AB 3. Ne Ymk: Dodbetry, 1991. Ifrition 17-22, AB 3A New Yad D-hilgdry, 2000.

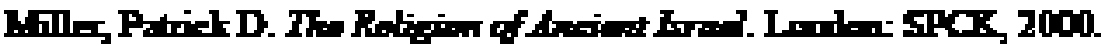

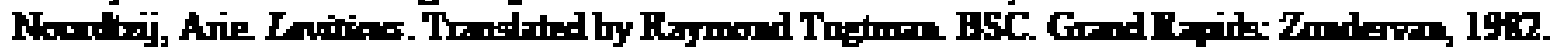

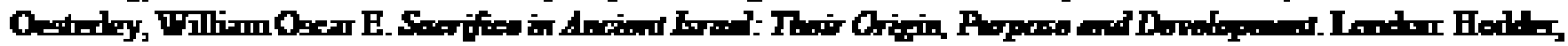
1937.

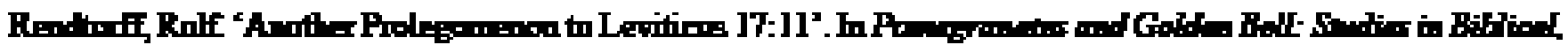

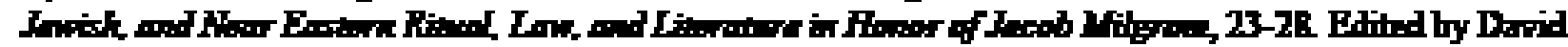

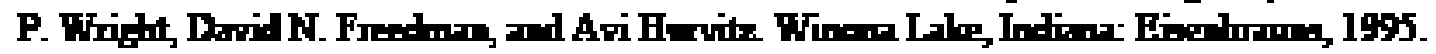

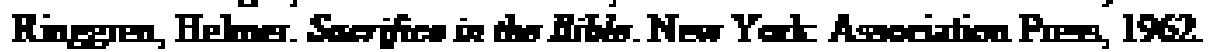

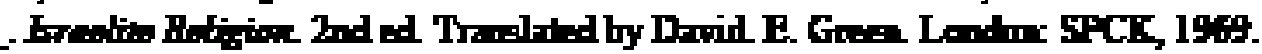

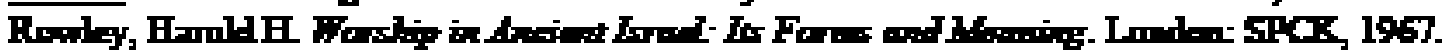

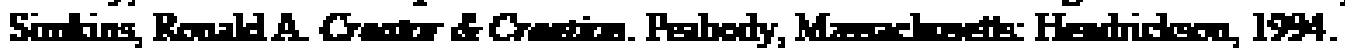

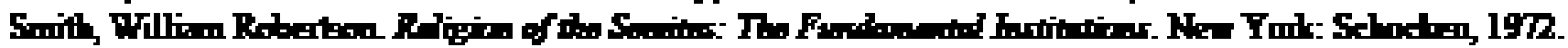

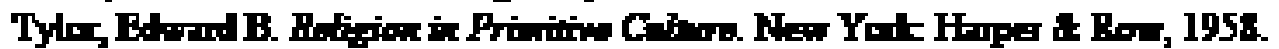

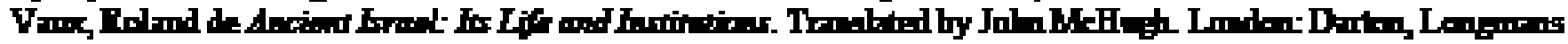
$\&$ Tod, 1961.

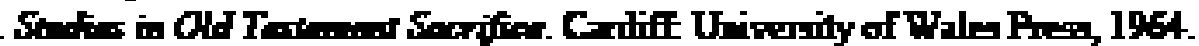

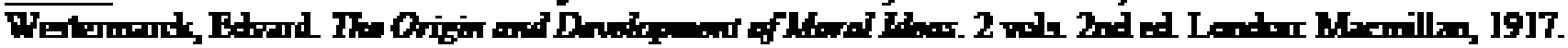

